University of Louisville

ThinkIR: The University of Louisville's Institutional Repository

Electronic Theses and Dissertations

1947

\title{
Studies on synthesis by enzymatic catalysis.
}

Charles Henry Wabnitz 1916-2004

University of Louisville

Follow this and additional works at: https://ir.library.louisville.edu/etd

Part of the Biochemistry, Biophysics, and Structural Biology Commons

\section{Recommended Citation}

Wabnitz, Charles Henry 1916-2004, "Studies on synthesis by enzymatic catalysis." (1947). Electronic Theses and Dissertations. Paper 2162.

https://doi.org/10.18297/etd/2162

This Master's Thesis is brought to you for free and open access by ThinkIR: The University of Louisville's Institutional Repository. It has been accepted for inclusion in Electronic Theses and Dissertations by an authorized administrator of ThinkIR: The University of Louisville's Institutional Repository. This title appears here courtesy of the author, who has retained all other copyrights. For more information, please contact thinkir@louisville.edu. 


\title{
UNIVERSITY OF LOUISVILIE
}

Studies on synthesis by enzymatic catalysis

\author{
A Bissertation \\ submitted to the Faculty \\ of the Graduate school of the University of Louisville \\ In Partial Fulfillment of the \\ Requirements for the Degree \\ of liaster of science \\ Department of Biochemistry
}

By

Charles Henry Wabnitz

Year

1947 


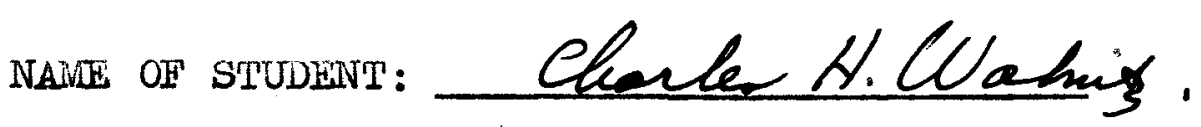

TITLE OF THESIS: STUDIES ON SYIPLHESIS

BY EIVZYMATTIC CATALYSIS

APPROVED BY READIVG CONWITILE CONPOSED OF THE FOLLOWIVG MENBBER:

Sames a Thunel Awtemberger NAIE OF DIRHCTOR: Allffomberqes. DATE: $3-2 \%, y$ 


\section{ACKNOWIEDGMENT}

The author is deeply indebted and sincerely greatful to Dr. A. W. Homberger, Professor and Head of the Department of Biochemistry at the University of Louisville School of Medicine, and to Dr.J.S. Long, Research Virector of the Levoe and Raynolds company, for making this research possible and for their sustained interest, splendid direction and invaluable advice concerning the many problems encountered during the course of this work. 
TABLE OF CONIYNTS

Page

I.INTRODUCTION..................... I

A. Reversibility of Enzyme Action........... 2

1. Theoretical.................... 2

2. Historical..................... 2

3. viscussion.................... 4

B. Purpose of This Research.............6 6

II. ENLYMATIC SYNIHESIS OF GLYCERIDES

FROM GLYCEROL AIND LINSEED OIL FAITIY ACIDS..... 7

מ. Objectives......................... 8

B. Problems....................... 8

c. Literature....................... 9

ע. Methods.......................... 12

E. Experimental.......................... 13

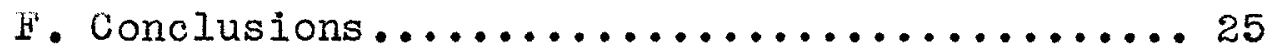

G. Summary $\ldots \ldots \ldots \ldots \ldots \ldots \ldots \ldots \ldots \ldots \ldots$

III. ENZYMATIC SYNTHESIS OF "SUGAR ESTERS"

FROLI DEXTROSE AVI LIVISEED OIL F'Al"I'Y ACIDS.... 31

4. Objectives.............................. 32

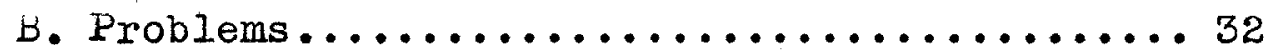

c. Experimental.................... 53

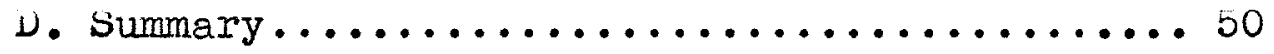

H. Conclusions ....................... 50

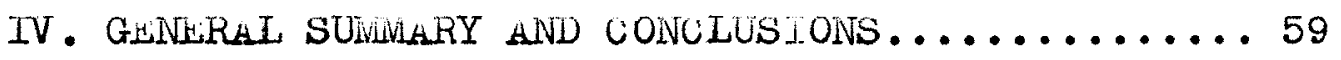

v. BIBLIOGRAPHY...................66 63 
I'he demonstration of the reversibility of enzyme action is not altogether new. Although not all enzymes have been found as yet to possess reversible action, neither is the field limited to the synthesis of merely a few compounds.

Enzymes are usually thought of as being catalysts and if they are to be classified as such one inight surmise that they should possibly be able to catalyze a reaction in either direction. That is, we might expect to find enzyme reactions reversible if the substrate conditions are properly controlled. Further considerations of theoretical bearing will be given in appropriate places throughout this work.

As far back as 1892 Tammann (I) and in 1898 Van't Hoff (2) mentioned the possibility of a reversal of enzyme action. since that time it has been repeatedly demonstrated by many workers that, as Tauber (3) so aptly states, "Under certain definite conditions reactions for some enzymes may be reversed."

Crort Hill (4) in 1898 claimed success in synthesizing maltose by digesting a forty per cent glucose substrate with yeast maltase at thirty degrees centigrade. This was perhaps the first demonstration of synthesis by enzymatic catalysis.

Later, Emerling (5) in 1910 showed that the substance thus synthesized according to Croft Hill's method was not maltose but iso-maltose. Other workers have repeated similar experiments with these sugars with positive results.

Bourquelot and Bridel (6) were able to synthesize the glucoside salicin using the enzyme emulsin as catalyst. Other glucosides have been synthesized by them and by other workers 
using emulsin and bottom fractions of brewers yeast as sources of enzymatic catalysts.

A compoum called "plastein" has allegedly been formed from peptones by several workers. Of special note in this field is the work of salter and Pearson (7) who were able to produce a plastein from the action of pepsin on a concentrated thyroid gland digest. They found that this plastein had a marked effect in relieving symptoms of thyroid deficiency whereas the original digest was ineffective.

wastneys and Borsook (8) resynthesized thirty-nine percent of a peptic digest of egg albumin. Other protein syntheses have recently been reported (9).

In 1923 Kay demonstrated synthesis of urea by action of urease on anmonium carbonate and carbamate mixture.

Many workers have demonstrated synthesis of various esters and glycerides through the agency of enzymatic catalysis. A review of the work done in this field will be given subsequently in this paper when more specific details concerning this particular field are discussed.

Just recently Hassid, Dourdorff and Barker (11) (12) obtained synthetic, crystalline sucrose from glucose-1-phosphate and fructose through the enzymatic catalysis of sucrose phosphorylase from Pseudomonas Saccharaphila.

The enzymatic synthesis of starch has also been recently announced. (13) (14)

It has therefore been demonstrated by many. workers in many different cases that various chemical compounds, many of which 
are of biochemical interest, can be synthesized in vitro by the apparent catalytic action of enzymes.

It must also be noted however that even though enzymes can catalyze synthesis, as sumner and Somers (14) point out, "this does not mean that every substance which is synthesized in plants and animals is built up by the same enzyme which is able to break it down."

For example, urease hydrolyzes urea but urea is not. necessarily synthesized in animals by urease but probably by the action of arginase upon arginine. Nevertheless, as has already been pointed out, urea can be synthesized by urease in vitro. In a similar way, starch is hydrolyzed to maltose by amylase but is synthesized apparently by dephosphorylation of glucose-1-phosphate by phosphorylase.

so, even though some enzymes may catalyze synthesis in the animal body, and even though we can demonstrate in vitro the reversibility of certain enzymes, it does not necessarily follow that synthesis must always be catalyzed by that same particular enzyme which will also hydrolyze the compound to be formed.

However, neither does this rule out the possibility that in at least some cases the same enzyme may both hydrolyze and also synthesize in the plant and animal according to the nature of the substrate and that possibly the concentrations of certain governing factors in the substrate may change so as to favor hydrolysis under one set of conditions and synthesis under another set of conditions. Of course there exists the possibility also 
that a separate enzyme is present for specific action under each set of conditions instead of one enzyme being capable of either hydrolysis or synthesis.

It has been found that in the synthesis of oil in such oil-bearing seeds as castor beans, that as the beans mature and as the oil is formed in the seed, the lipase content increases and the water content decreases. In gemination on the other hand, the water content is said to increase and the lipase hydrolyzes the oil. It may be inferred from this that possibly the same lipase is capable of either synthesizing or hydrolyzing the oil according to the substrate arailable. At least this has apparently been the general assumption of workers in this field.

It has also been suggested, although never adequately proven nor disproven, that lipase may play an important role in the resynthesis of fat in the epithelial lining of the intestine or even in the Golgi apparatus which is apparently the site of fat resynthesis.

Wany interesting examples of enzymatic synthesis have been reported in the literature other than the comparative few listed here. This field of synthesis as brought about by the agency of enzymatic catalysis presents an enormous array of research possibilities the results of which may someday throw much-needed light upon the role of enzymes in the complex and intricate metabolism and catabolism in both health and disease of both plants and animals. There also exist many possibilities for the employment of enzymatic catalysis to promote synthesis on a large scale in various industries where at present much time and a large quantity of energy of one kind or another is required. 
It must be pointed out however that enzyme work is not easily carried out nor are the results of enzymatic experimentation always readily interpreted or evaluated. Ihis is aue in part to the intangible nature of enzymes themselves and in part to the many entities and groups of entities which definitely effect them.

Therefore, for the most part, in enzyme work of the nature herein reported, methods of pure exploration must of necessity be employed and results must be interpreted cautiously and any conclusions drawn should be accepted with reservations. It is quite difficult in many cases to adequately evaluate work of this nature, but the task is somewhat easier if an open mind is kept concerning the many difficulties involved and if the pioneering aspect of such research attempts is properly considered.

In brief, the purpose of the investigation herein reported has been to seek further evidence concerning the possibility of synthesizing glycerides in vitro through the reversible, catalytic action of lipase in order to throw some light upon the possible mechanism concerned in the enzymatic synthesis of oils and fats in plants and animals as well as the possibility of synthesizing tailor-made glyceride or esters of fatty acids and polyhydric alcohols in the laboratory.

The following pages of this work represent studies and experimental results concerning these problems as carried on over a period of four years in the research laboratory of the Lepartment of biochemistry at the university of Louisville school of ivedicine. 
ENZYMATIC SYNTHESIS OF GLYCERIDES

FROM GLYCAROL AIND LINSEED OIL FATIY ACIDS 
'the first goal set to be achieved in this work was to effect a decrease in the acid number of a mixture containing linseed oil fatty acids and glycerol through the catalytic action of lipase.

It has been assumed, relative to results obtained by other investigators in work of this nature that oil synthesis occurs in proportion to the amount of decrease in free fatty acid content of the substrate used.

since so many factors may effect the results in work of this kind, each problem must of necessity be solved more or less as it appears in relation to the whole before the main objective is attained and each individual problem generally bears some relationship to all of the other problems involved. Generally speaking however the problems resolved themselves into two groups. In the first place, there were problems concerning the enzyme or catalyst used, such as the best source of the enzyme, methods of extraction and activation, and the proper use of it in order to obtain maximum results. In the second place, there were problems concerning the substrate, such as the necessity to acertain the proper ratio of glycerol to fatty acids required to obtain optimum synthesis, the effects of various concentrations of water with respect to different glycerol-fatty acid ratios and to different enzyme preparations, as well as effects of pH, temperature and other factors.

Nany workers have been able to synthesize various esters through the apparent catalytic agency of lipase from an animal source. 
F'or example, in 1900 Kastle and Loevenhart (15) synthesized ethyl butyrate from ethyl alcohol and isobutyric acid with pancreatic lipase as catalyst.

Pottevin (16) in 1904 synthesized methyl oleate and later (1905) he also obtained esterification using pancreatic lipase with oleic acid and ethyl, methyl, propyl, isopropyl and other alcohols $(17)$.

Sbout this same time, Bodenstein and Leitz (18) (19) esterified butyric acid and isoamyl alcohol using pancreatic lipase.

Glycerol esters have also been synthesized by several workers using pancreatic lipase.

For example, Hanriot (20) produced monobutyrin by the catalytic action of pancreatic lipase on butyric acid and glycerol, and Pottevin (21) produced mono and di oleins with pancreatic lipase. Triolein was produced by laylor (22) using pancreatic powder, glycerol and oleic acid.

Hamsik (23) found that powder prepared from the mucous membrane of the small intestine of horses, sheep and hogs caused synthesis with oleic acid and glycerol; (24) pancreatic lipase of the pig caused fat synthesis with palmitic and stearic acids and glycerol but similar preparation from cattle and dogs did not do this.

still other workers have used lipase from a vegetable source, namely from castor beans, to effect synthesis of glycerides. It was first shown by $J$. Reynolds Green in 1889 (25) that germinating seeds of the castor oil plant contain an enzyme 
capable of hydrolyzing castor oil. an industry based upon this discovery has come into being in which ground, ungerminated castor oil seed is mixed with an ordinary fatty oil and a small quantity of acid (preferably acetic). The fatty matter is almost completely hydrolyzed to fatty acid and a very pure glycerol. 'I'he reaction takes place rapidly and just a little above room temperature.

'laylor (26) using castor bean lipase and one-fourth more than the molecular quantity of glycerol necessary to produce a triglyceride, was able to synthesize triolein from glycerol and excess fatty acid normal to fat by allowing the enzyme to contact the substrate for six months. He was able to separate the neutral fat produced and identified it.

'I'witchell (27) tound what he called a "synthetic lipase" (naphthalenestearosulfonic acid) which would cause fatty acid and glycerol to condense in presence of water.

The experimental fact that lipase did not produce complete hydrolysis led vunlap and Gilbert (28) to successful attempts to synthesize fats through the action of oil-free castor lipase on a glycerol-fatty acid substrate. 'they were able to show a disappearance in eleven days of more than twenty-six per cent of the total oleic present. 'They also used glycerol in excess of the amount theoretically necessary to esterify the oleic acid. Synthesis was measured by decrease in acid value:

welter (29) also synthesized fats from fatty acids and glycerol with castor lipase, and welter and Ivanov (30) have shown experimentally that the synthetic agent was a lipase. 
armstrong and Gosney (31) in enzyme studies on "The Correlation of synthetic and Hydrolytic Hctivity" of castor lipase found that using oleic acid and glycerol in absence of all but traces of water, thirty-eight per-cent oleic acia combined as glyceride in 70 hours. 'they found that glyceride synthesis diminished with increase in water content and increased with an increase in glycerol content.

solander (32) obtained eleven per-cent synthesis of oleic acid and glycerol in twelve days using castor lipase. sym (33) developed a method for synthesizing esters using pancreas powder and a substrate in which the products are removed from the place of formation as soon as they are formed. 'this is done by using a medium such as carbon tetrachloride or benzene to dissolve the ester as it is formed at the interface of the aqueous substrate. Wany esters have been synthesized through the agency of enzymatic catalysis by this technique including esters of cholesterol butyrate, butyl benzoate, etc., and Rona and associates (34) synthesized wax (cetyl palmitate) by this same method.

The studies set forth in this first section of the present paper have been confined to the synthesis of glycerides from glycerol and a mixture of fatty acias as obtained from the hydrolysis of linseed oil. Enzyme preparations from both plant and animal sources as well as Twitchell's "synthetic lipase" were used to furnish the catalyst to effect synthesis. The active catalyst was assumed to be the enzyme lipase in the case of the plant and animal preparations. 
Briefly, the method used was as follows: A substrate composed of various proportions of glycerol, linseed oil fatty acids and water was prepared. To this substrate was added an enzyme preparation. This was then thoroughly mixed and an aliquot portion removed to another flask and weighed, dissolved in ninety-five per cent ethyl alcohol and titrated for its acid number with tenth-normal sodium hydroxide. Ihis gave the free fatty acid content of the original substrate. then the substrate was kept at a constant temperature and constantly stirred. an aliquot portion was removed every twenty-four hours and the acid number was again determined as before. A decrease in the acid number of the substrate, i.e. the decrease of free fatty acid content, was taken as a measure of the extent of glyceride synthesis assuming that the decreased portion of the free fatty acids combined with some of the glycerol forming a glyceride.

One of the first major problems was to find a good source of lipase which would give naximum synthesis. Uf the various sources of lipase it seened probable from the results of other workers that castor beans and pancreatin powder would be most suitable for this. so, having access to more castor beans than to pancreatin at the time, it was decided to employ lipase from castors first.

Yishio l'anaka in 1910 (35) prepared a lipase from castor beans which was said to be very active. as a matter of fact, this preparation hat been used industrially for the hydrolysis of oils and is said to have yielded a high percentage of very pure glycerol. Oil digested at thirty to thirty-tive degrees 
Centigrade with three to four per cent of the aried enzyme powder and six to ten times as much water as powaer yielaed: ninety per cent glyceride hydrolysis within seven to ten hours. armstrong and Gosney (56) used a modification of lanaka's preparation with good results in studies on the synthetic powers of lipase on a substrate containing glycerol and fatty acias derived from the hydrolysis of olive oil.

It was decided therefore that perhaps this preparation should work well for the problem at hand, so some of it was prepared according to the above methods. To prepare this castor powder the oil is first removed either by ether extraction or by pressing and the residue is then digested with dilute acid. It is then washed thoroughly with water to remove all watersoluble matter and the pasty mass is then dried at a temperature OI not more than forty degrees centigrade:

while this oil-free preparation was being made, preliminary work was carried out using castor beans containing their original oil content. Ihis was done in the first place because several workers had previously noted that lipase may lose its activity in aqueous solution in absolute absence of oil and in the second place because of the belief that lipase would effect synthesis in preference to hydrolysis if. placed in the proper substrate even in the presence of oil. Ihe glycerol-fatty acidwater substrate in this case was about sixty times the volume of the oil present in the castors used.

iurthermore, in work on whe Synthesis of itats by the iction of tnzymes" by Lunlap and Gilbert (37) a large excess of glycerol was used in the substrate with good results. so, as a starting point, a glycerol-fatty acid ratio of three to one was 
tried first. Reports in the literature seemed to indicate that castor lipase apparently worked only in an acid medium. There was some conflict of opinion on this point however and some workers found that castors treated first with dilute acid contained active lipase even if not used in a substrate of acid pH. In preliminary experiments using kicinus Largus castor beans containing their original oil content the results(liables I and II) indicated:

1. The catalyst effecting synthesis is apparently an enzyme because heat destroys its synthetic action.

2. This enzyme is not found free in the castor beans but exists as a zymogen because untreated castors give negative results whereas acid-treated castors give positive results.

3. Better results are obtained if the temperature is kept constant at about thirty degrees Centigrade.

The enzyme preparation used in these experiments was prepared by grinding the fine, oily meal, obtained by grinding castor beansfin a food chopper, with approximately one-tenth normal sulfuric acid in proportion of 50 grams of the meal to $150 \mathrm{cc}$ of the acid. This mixture was then shaken in a flask for about 15 minutes and then allowed to stand about 5 minutes until the hulls settled after which the upper portion was decanted off, filtered, washed with water and the residue airdried at from 32 to 37 degrees centigrade overnight.

l'he substrate ratios as given in the following tables are indicated as $\mathrm{G}-\mathrm{A}-\mathrm{W}$, denoting the ratio of glycerol-fatty acidwater. 
TABLEF I

PRELIMINARY EXPERIMENTS WIIH RICINUSS LARGUS CASTORS CONTAINING THEIR ORIGINAL OIL CONTHNI

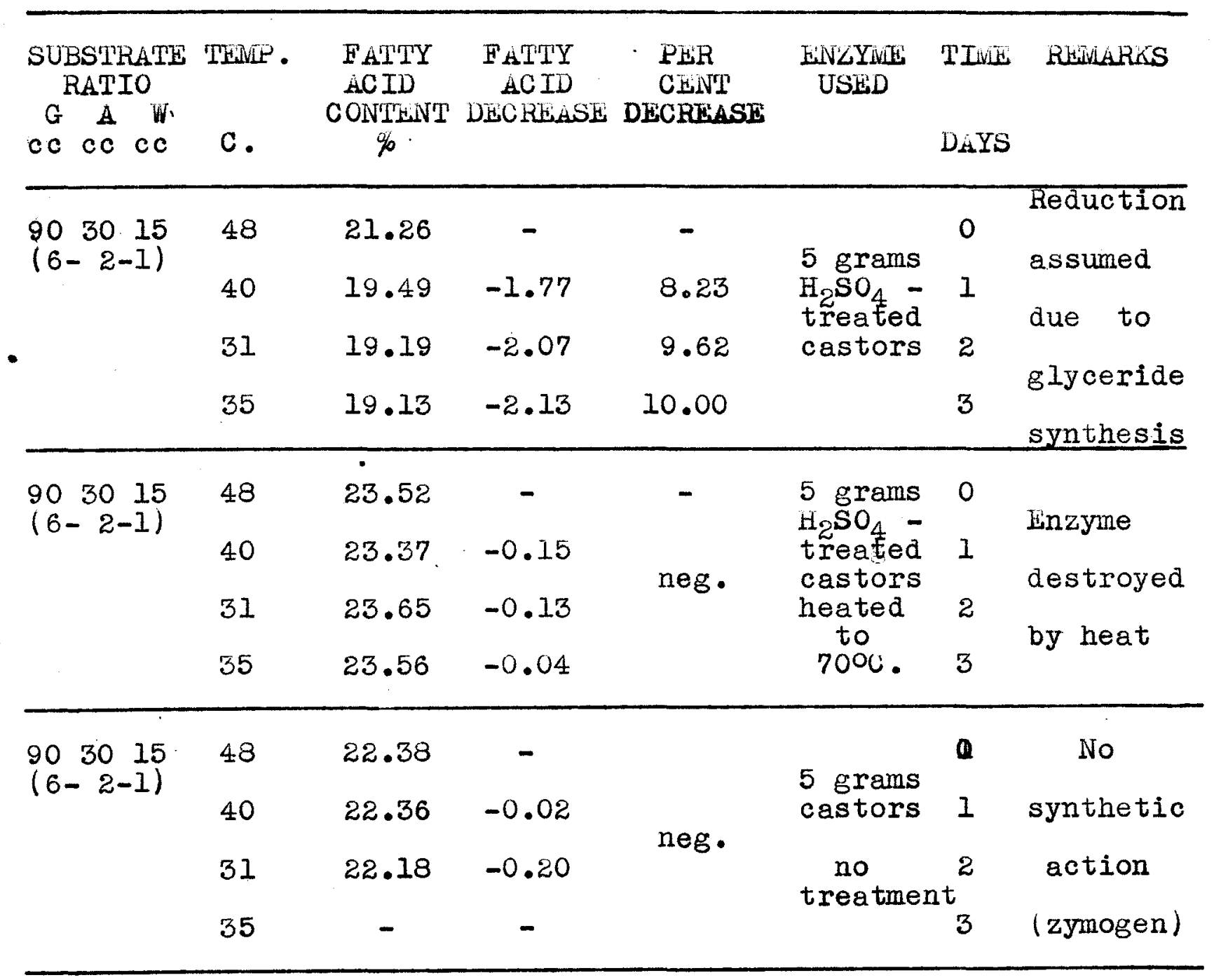


TABLE II

PRELIVINARY EXPLRIVINTS WITH RICINUS LARGUS CASTORS CONTAINING 'HHIR ORIGINAL OIL CONIENT

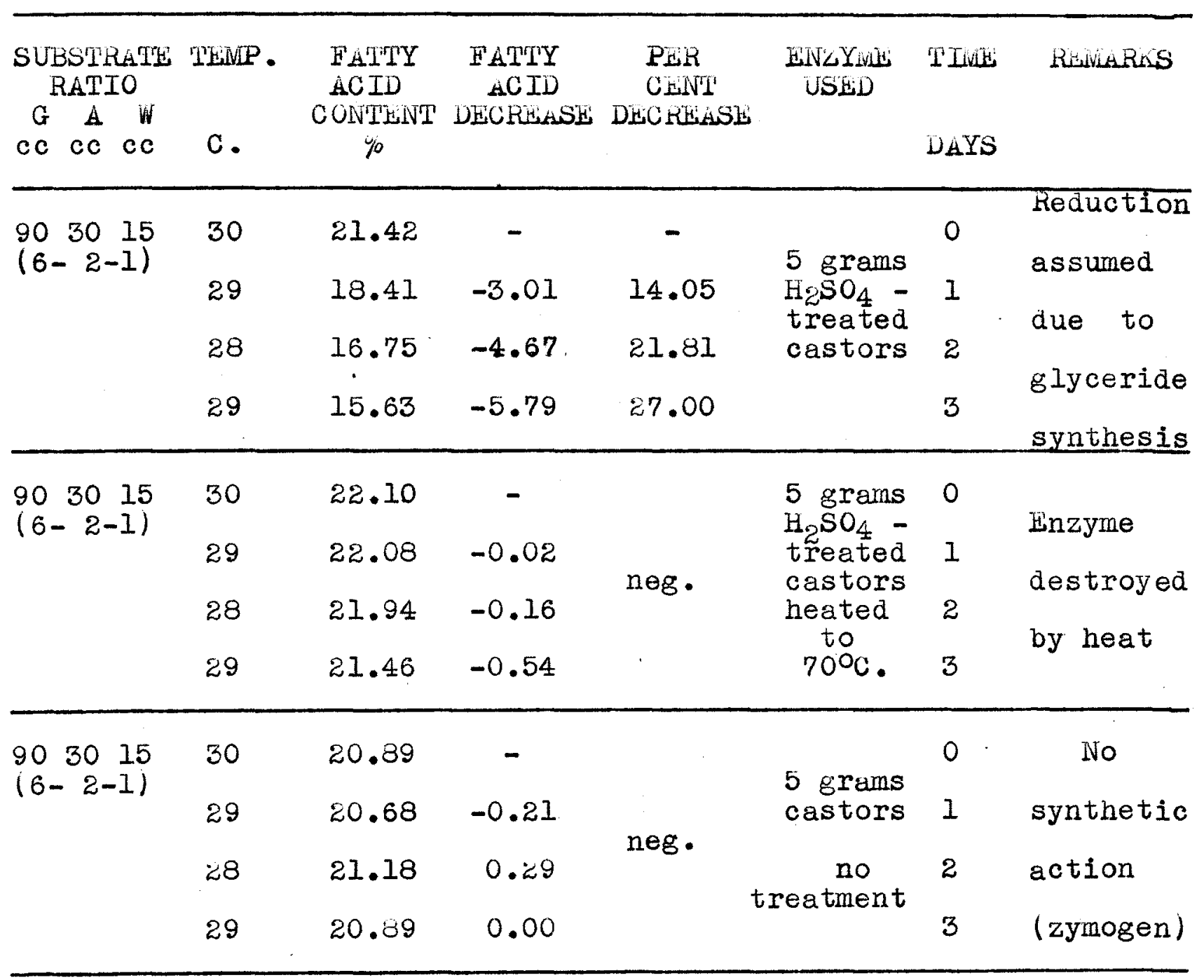


In other preliminary experiments (Table III) more than twice the amount of free futty acid disappeared f'rom the substrate when acid-treated, oil-free Ricinus cargus castor powder was used with the sume G-A-W ratio. It was further reaffirmed in these experiments that the catalyst effecting glyceride synthesis is apparently an enzyme since no changes of fatty acid content of the substrate (within range of the experimental error involved) occured when the enzyme preparation was heated to $70^{\circ} \mathrm{C}$. before use. results again revealed that dilute acid treatment is necessary to free the active principle involved.

The castor enzyme preparations used in these experiments were prepared as follows: Oil-free castor bean powder was first prepared by exhausted extraction of the ground, Ricinus cargus castor beans with ethyl ether by means of the soxhlet technique. Hive grams of this oil-free castor bean powder were ground in a mortar with $25 \mathrm{cc}$ of approximately tenth-normel sulfuric acid. Ihis was then shaken 15 minutes, incubated one hour at $37^{\circ} \mathrm{C}$. and filtered. The residue was then washed two or three times with water and allowed to drain to a semi-wet condition. The moist residue was employed. Ihis consisted in each case of about thirteen grams of moist residue containing originally five grams of the oil-free castor meal.

It was also found that Mierck's Pancreatin powder (untreated) gave results of about the same magnitude as the acidtreated, oil-free castors under similar conaitions. Hesults showed that Pancreatin contains an enzyme capable of catalyzing glyceride synthesis and that this enzyme exists in the free state in this preparation. 
TABIE III

HXPLRIVENIS' WITH OIL-FREE RICIINUS ZARGUS CASTORS.

AND IVERCK PANCREATTN POWDER

\begin{tabular}{|c|c|c|c|c|c|c|c|}
\hline 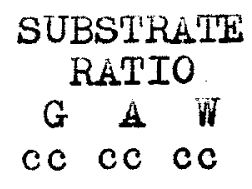 & $\begin{array}{l}\text { TEMP. } \\
\text { C. }\end{array}$ & $\begin{array}{c}\text { FATTY } \\
\text { ACID } \\
\text { CONTENT } \\
\%\end{array}$ & $\begin{array}{c}\text { FATTY } \\
\text { ACID } \\
\text { DE'CREASE }\end{array}$ & $\begin{array}{c}\text { PER } \\
\text { CENT } \\
\text { DECREASE }\end{array}$ & $\begin{array}{l}\text { EINZYHE } \\
\text { USED }\end{array}$ & $\begin{array}{l}\text { PIVEE } \\
\text { DAYS }\end{array}$ & REIVEARKS \\
\hline $\begin{array}{r}903015 \\
(6-2-1)\end{array}$ & $\begin{array}{l}26 \\
25 \\
25 \\
26\end{array}$ & $\begin{array}{r}16.50 \\
8.79 \\
8.72 \\
8.73\end{array}$ & $\begin{array}{c}- \\
7.71 \\
7.78 \\
7.77\end{array}$ & $\begin{array}{c}- \\
47.1 \\
47.2 \\
47.2\end{array}$ & $\begin{array}{l}5 \text { grams } \\
\mathrm{H}_{2} \mathrm{SO}_{4}- \\
\text { treated } \\
\text { castors }\end{array}$ & $\begin{array}{l}0 \\
1 \\
2 \\
3\end{array}$ & $\begin{array}{l}\text { Reduction } \\
\text { assumed } \\
\text { due to } \\
\text { glyceride } \\
\text { synthesis }\end{array}$ \\
\hline $\begin{array}{l}903015 \\
(6-2-1)\end{array}$ & $\begin{array}{l}26 \\
25 \\
25 \\
26\end{array}$ & $\begin{array}{l}20.72 \\
20.61 \\
20.85 \\
20.90\end{array}$ & & neg. & $\begin{array}{l}5 \text { grams } \\
\mathrm{H}_{2} \mathrm{SO}_{4}- \\
\text { treated } \\
\text { castors } \\
\text { heated } \\
\text { to } \\
70^{\circ} \mathrm{C} .\end{array}$ & $\begin{array}{l}0 \\
1 \\
2 \\
3\end{array}$ & $\begin{array}{l}\text { Enzyme } \\
\text { destroyed } \\
\text { by heat }\end{array}$ \\
\hline $\begin{array}{l}903015 \\
(6-2-1)\end{array}$ & $\begin{array}{l}26 \\
25 \\
25 \\
26\end{array}$ & $\begin{array}{l}23.19 \\
22.97 \\
23.09 \\
23.25\end{array}$ & & neg. & $\begin{array}{l}5 \text { grams } \\
\text { castors } \\
\text { not } \\
\text { treated } \\
\text { with } \\
\mathrm{H}_{2} \mathrm{SO}_{4}\end{array}$ & $\begin{array}{l}0 \\
1 \\
2 \\
3\end{array}$ & $\begin{array}{l}\text { No } \\
\text { synthetic } \\
\text { action } \\
\text { (zymogen) }\end{array}$ \\
\hline $\begin{array}{l}90 \quad 3015 \\
(6-2-1)\end{array}$ & $\begin{array}{l}26 \\
25 \\
25 \\
26\end{array}$ & $\begin{array}{l}22.48 \\
18.46 \\
14.89 \\
11.05\end{array}$ & $\begin{array}{c}- \\
-4.02 \\
-7.57 \\
-11.43\end{array}$ & $\begin{array}{c}.7 \\
17.9 \mathrm{~Pa} \\
33.8 \mathrm{un} \\
50.8\end{array}$ & $\begin{array}{l}5 \text { grams } \\
\text { ncreatin } \\
\text { powder } \\
\text { merckl } \\
\text { treated }\end{array}$ & $\begin{array}{l}0 \\
1 \\
2 \\
3\end{array}$ & $\begin{array}{l}\text { Reduction } \\
\text { assumed } \\
\text { due to } \\
\text { glyceride } \\
\text { synthesis. } \\
\text { No zymogen }\end{array}$ \\
\hline$\left(\begin{array}{lll}0 & 30 & 15 \\
6 & -2 & -1\end{array}\right)$ & $\begin{array}{l}26 \\
25 \\
25 \\
26\end{array}$ & $\begin{array}{l}21.87 \\
21.66 \\
21.18 \\
20.79\end{array}$ & $\begin{array}{c}- \\
-0.21 \\
-0.69 \\
-1.08\end{array}$ & neg. $\begin{array}{r}\text { Pa } \\
\text { un } \\
\text { to }\end{array}$ & $\begin{array}{l}5 \text { grams } \\
\text { ncreatin } \\
\text { powder } \\
\text { werckl } \\
\text { treated } \\
\text { Heated } \\
70^{\circ} \mathrm{C} .\end{array}$ & $\begin{array}{l}0 \\
1 \\
2\end{array}$ & $\begin{array}{l}\text { Linzyme } \\
\text { destroyed } \\
\text { by heat }\end{array}$ \\
\hline
\end{tabular}


Under experimental conditions similar to those just described, soy beans, both acid-treated and untreated, gave negative results. Peanuts and also oil-free linseed meal gave unsatisfactory results as did unripened castor beans. Unripened castor beans were used in which the oil was just beginning to form with the idea in mind that perhaps they would contain more lipase or perhaps some catalyst especially suitable for oil synthesis.

Having obtained positive results with the 6-2-1 G-A-i . ratio using werck's Pancreatin powder and having found, in further preliminary experiments not presented here, that a reversal of the G-A ratio yielded higher results, it was decided to find out just how much of this Pancreatin powder was necessary to obtain maximum synthesis using the 2-6-1 G-A-W ratio. Results (Table IV) indicated that five grams of this powder was optimum quantity for maximum results.

Having finally obtained positive results of over fifty percent reduction in each case with either a $G-4$ ratio of $2-6$ or 6-2, attention was now turned to the effect of variation of the water content of the substrate.

It was decided to compare some of these substrate results with results obtained by armstrong and Gosney (38) who made extensive studies on the effect of water on both hydrolysis and synthesis of glycerides. They found that water had a retarding effect upon both conditions of equilibrium but that apparently at least a film of water is necessary at the interface of the system where interaction takes place and that "if this be removed, action comes to an end." 
TABLE IV

EXPERTMENTS USIIVG WUERCK PANCREATIN POWDER

\begin{tabular}{|c|c|c|c|c|c|c|c|c|c|}
\hline $\begin{array}{l}\text { SUBSTh } \\
G-A-W\end{array}$ & $\begin{array}{l}\text { Ring } \\
\text { G } \\
c c\end{array}$ & $\begin{array}{c}\mathrm{RA} \\
\mathrm{A} \\
\mathrm{CC}\end{array}$ & $\begin{array}{l}{ }_{W} \\
\mathrm{CC}\end{array}$ & $\begin{array}{l}\text { TEIVIP } \\
\mathrm{c} \text {. }\end{array}$ & $\begin{array}{l}\text { Fán'IYY ACID } \\
\text { CONILNI }\end{array}$ & $\begin{array}{l}\text { D FATTY } \\
\text { ACID } \\
\text { DECHEASE }\end{array}$ & $\begin{array}{c}\text { PLR } \\
\text { CENT } \\
\text { LECREASH }\end{array}$ & $\begin{array}{l}\text { ENLYWE } \\
\text { USED }\end{array}$ & $\begin{array}{l}\text { TLVIE } \\
\text { DAYS }\end{array}$ \\
\hline $2-6-1$ & 30 & 90 & 15 & $\begin{array}{l}29 \\
30 \\
30 \\
29\end{array}$ & $\begin{array}{l}22.29 \\
22.66 \\
22.41 \\
22.69\end{array}$ & & neg. & 0.18 . & $\begin{array}{l}0 \\
1 \\
2 \\
3\end{array}$ \\
\hline $2-6-1$ & 30 & 90 & 15 & $\begin{array}{l}29 \\
30 \\
30 \\
29\end{array}$ & $\begin{array}{l}23.00 \\
23.24 \\
22.54 \\
22.36\end{array}$ & & neg. & 0.58 . & $\begin{array}{l}0 \\
1 \\
2 \\
3\end{array}$ \\
\hline $2-6-1$ & 30 & 90 & $\begin{array}{r}15 \\
.\end{array}$ & $\begin{array}{l}29 \\
30 \\
30 \\
29\end{array}$ & $\begin{array}{l}22.25 \\
21.55 \\
20.51 \\
19.95\end{array}$ & $\begin{array}{l}-\overline{7} \\
0.92 \\
1.74 \\
2.30\end{array}$ & $\begin{array}{r}4 . \overline{08} \\
7.82 \\
10.34\end{array}$ & $1.0 \mathrm{~g}$. & $\begin{array}{l}0 \\
1 \\
2 \\
3\end{array}$ \\
\hline $2-6-1$ & $3 \theta$ & 90 & 15 & $\begin{array}{l}29 \\
30 \\
30 \\
29\end{array}$ & $\begin{array}{r}21.49 \\
14.93 \\
10.71 \\
9.18 .\end{array}$ & $\begin{array}{r}6 . \overline{56} \\
10.78 \\
12.31\end{array}$ & $\begin{array}{l}30.50 \\
50.20 \\
57.30\end{array}$ & $5.0 \mathrm{~g}$. & $\begin{array}{l}0 \\
1 \\
2 \\
3\end{array}$ \\
\hline $2-6-1$ & 30 & 90 & 15 & $\begin{array}{l}22 \\
30 \\
30 \\
29\end{array}$ & $\begin{array}{r}20.31 \\
10.94 \\
8.99 \\
8.72\end{array}$ & $\begin{array}{r}- \\
9.37 \\
11.32 \\
11.59\end{array}$ & $\begin{array}{l}- \\
46.20 \\
55.70 \\
57.10\end{array}$ & $10.0 \mathrm{~g}$ & $\begin{array}{l}0 \\
1 \\
2 \\
3\end{array}$ \\
\hline $8-6-1$ & 30 & 90 & 15 & $\begin{array}{l}29 \\
30 \\
30 \\
29\end{array}$ & $\begin{array}{l}22.71 \\
22.71 \\
22.58 \\
23.09\end{array}$ & & neg. & $\begin{array}{l}\text { none } \\
\text { blank) }\end{array}$ & $\begin{array}{l}0 \\
1 \\
2 \\
3\end{array}$ \\
\hline
\end{tabular}


Using the same method as they and an enzyme prepared in the same way as outlined by armstrong and Gosney (38), results were obtained using the fatty acids from linseed oil which were very similar to the results of their work in which fatty acids from olive oil were employed. Ihis comparison of results is shown in liable $V$ and in Graph $I$.

The enzyme preparation used in these experiments was prepared as follows: fifty grams of mature, fresh castor beans (decorticated) were ground in a mortar with a little petroleum ether. This ground residue was then extracted eight hours with petroleum ether using the soxhlet technique. It was then allowed to stand in petroleum ether overnight and the residue was then further extracted another eight hours as just described using ethyl ether. Having stood over night in ethyl ether, the residue was then air-dried, ground again in a mortar with ethyl ether and centrifuged. This residue was air-dried and ground to a powder in a mortar. The yield of 14.5 grams of dry powder thus obtained was treated with $120 \mathrm{ml}$ of approximately tenth-normal acetic acid for twenty minutes at $30^{\circ} \mathrm{c}$. and filtered. The resioue was washed with water and then dried at $37^{\circ} \mathrm{C} .24$ hours after which it was again powdered in a mortar. lihe final yield was seven grams of powder.

$$
\text { Results were negative using fatty acids from linseed oil }
$$
and sulfuric acid-treated castor beans containing their original oil content with each of the following: pentaerithritol, maltose, a-methyl-d-glucoside, dextrose, levulose and galactose. 


\section{TABLE V}

RESULIS USTHG ARUSTRONG AND GOSNEY WOUIFICATION

OF TANAKA'S EIVZYivit PREPARATION

WITH GLYCHROL AND LINSEED OIL FATTY ACIDS

\begin{tabular}{|c|c|c|c|c|c|c|}
\hline $\begin{array}{l}\text { SUBSTRATE } \\
\text { RATIO } \\
\text { G A } \\
\text { cc cc cc }\end{array}$ & $\begin{array}{l}\text { TEMP. } \\
\text { C. }\end{array}$ & $\begin{array}{c}\text { FATTY } \\
\text { ACID } \\
\text { CONTENT } \\
\%\end{array}$ & $\begin{array}{c}\text { FAPTY } \\
\text { ACID } \\
\text { DECREASE }\end{array}$ & $\begin{array}{c}\text { PER } \\
\text { CEIVT } \\
\text { DECREASE }\end{array}$ & $\begin{array}{l}\text { ENZYNE } \\
\text { USED }\end{array}$ & $\begin{array}{l}\text { TLUE } \\
\text { HOURS }\end{array}$ \\
\hline \multirow{6}{*}{$\begin{array}{ccc}3 & 30 & 0 \\
(1-10 & -0)\end{array}$} & 29 & 80.8 & - & - & \multirow{6}{*}{$\begin{array}{l}3 \text { grams } \\
\text { castor } \\
\text { powder }\end{array}$} & 0 \\
\hline & 29 & 77.7 & 3.1 & 3.8 & & 1 \\
\hline & 29 & 71.4 & 9.4 & 11.6 & & 6 \\
\hline & 29 & 64.6 & 16.2 & 20.0 & & 24 \\
\hline & 29 & 52.6 & 28.2 & 34.9 & & 48 \\
\hline & 29 & 51.5 & 29.3 & 36.2 & & 72 \\
\hline \multirow{6}{*}{$\left.\begin{array}{ccc}3 & 30 & 0 \\
(1-10 & -0\end{array}\right)$} & 29 & 80.6 & - & - & Blank & 0 \\
\hline & 29 & 82.3 & 1.7 & - & using & 1 \\
\hline & 29 & 81.0 & 0.4 & - & 2 grams & 6 \\
\hline & 29 & 76.0 & 4.6 & 5.7 & powder & 24 \\
\hline & 29 & 77.0 & 3.6 & 4.5 & heated & 48 \\
\hline & 29 & 77.8 & 2.8 & 3.4 & to $93^{\circ} \mathrm{C}$. & 72 \\
\hline
\end{tabular}




\section{GRAPH I}

COMPARISON OF RESULTS REPORIED BY ARMSTRONG AND GOSNEY WITH RESULTS OBTAINED IN PRESENT WORK

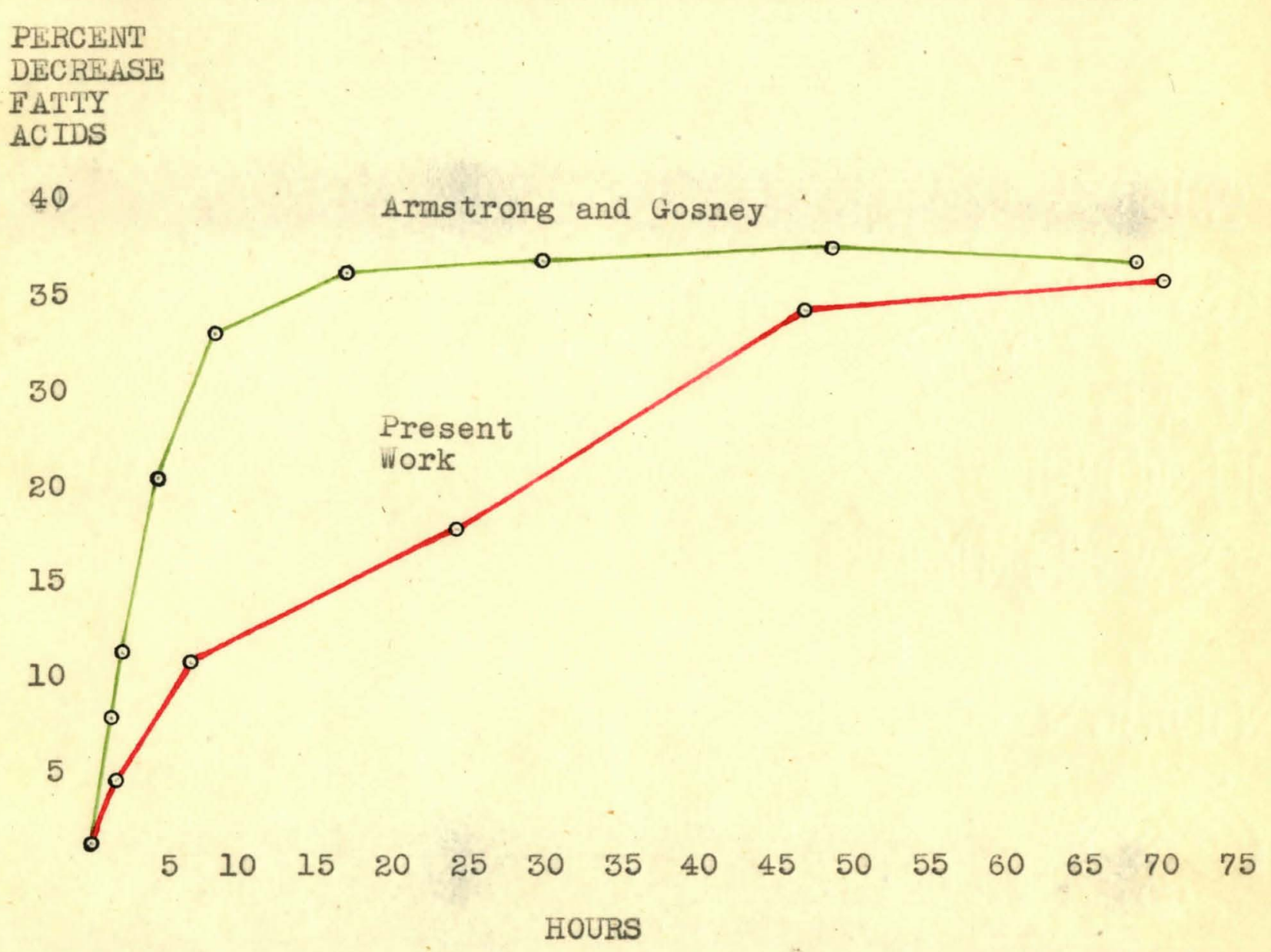


Whether an enzyme reaction is one say of hydrolysis or one of synthesis depends among other things upon the ratio of the components of the substrate. Hor example, when dealing with hydrolytic enzymes we should perhaps be able theoretically to increase synthesis by decreasing the water content of the substrate in the presence of stoichiometric proportions of the other components.

$\mathrm{H}_{2}-\mathrm{C}-\mathrm{OH}$

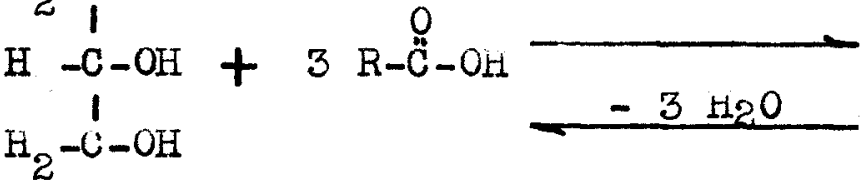

Glycerol Fatty Acid (A) (B)

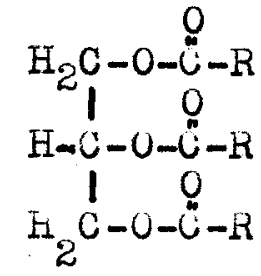

Glyceride

$(\mathrm{AB})$

It is obvious here that a catalyst may accelerate the reaction in either direction according to the conditions of the substrate. The concentrations of the substrate components are the main, deciding factors concerning whether hydrolysis or synthesis occurs. Hlso, according to the Law of ivess action, which states that the rate of reaction between any two substances in a mixture is proportional to the product of the active masses of these substances,

$$
\frac{(A) x(B)}{(A B) \frac{x}{x}\left(H_{2} O\right)}=K \quad \text { If }\left(H_{2} O\right) \text { increases, then }(A) x(B) \text { increases. }
$$

From a theoretical standpoint therefore, considering these and other mechanisms of reversible enzyme reactions, one can surmise that synthesis through the catalytic agency of an enzyme may be a possibility if the concentrations of the substrate components are controlled.

If one considers an enzyme reaction according to the old, key and lock conception of H'isher, then he might expect that possibly, under proper conditions, an enzyme such as lipase which 
will unlock a glyceride such as linseed oil, may also be made to re-lock the components. inuch work has been reported in the literature, especially in recent years, to substantiate the fact that enzymes do effect synthesis under proper substrate conditions.

In further extensive work therefore, an attempt was made to fina out just what conditions are necessary in order to cause lipase to synthesize glycerides of linseed oil fatty acids.

As we have seen from theoretical considerations, the absence of water should cause synthesis to proceed in a reversible reaction of the type mentioned. This particular point, i.e. the effect of the presence or absence of water in a substrate on enzymatic synthesis, is one of the major discrepancies among conflicting reports of workers in this particular field.

In so many cases in enzyme work of this kind it seems that the facts of experimentation throw out many nice, theoretical explanations concerning the possible mechanisms involved in the process. This was found to be the case in the present work, since the use of stoichiometric quantities of substrate components did not always give maximum results. spparently one reason why the Law of Mass Action is not always applicable in enzyme reactions is the fact that apparently so many of these reactions occur at the interface of colloid surfaces where the actual concentrations are not easily controlled.

Table VI shows the effect of various amounts of water on a G-A ratio of approximately stoichiometric proportions for combination of the fatty acids and glycerine as triglyceride: Note however that the results here are not as high as those obtained with the same type of enzyme preparation and the 6-2-1 
ratio as previously noted in lable III where the results were about $47 \%$ decrease of free fatty acids.

It was felt however that some ratio of substrate components would yield maximun results of synthesis and therefore work was planned in a purely exploratory fashion to find the best conaitions for obtaining glycerol synthesis of the particular problem at hand regardless of theory.

some thirty-six experiments were run incluaing some two hundred separate substrates in which various substrate ratios were used with various enzyme preparations.

liable VII contains a composite of positive results from these experiments listed in declining order. I'hose positive results, along with indifferent results (in which a decrease of fatty acid was followed by either less decrease or an increasel and with negative results, were compiled together for each different enzyme used so that the G-A-W ratio giving maximum synthesis could be acertainea. ior each particular enzyme preparation. in example of this is shown in IableVIII.Conclusions concerning the other enzyme oreparations were arrived at in the same way. After correlation of all data obtained in this present work it was found that each type of enzyme preparation gives a maximu yield with a definite $G-A-$ if ratio of its own.

It is evident (Table VII) that of the various G-A-H ratios tried with each particular enzyme, the following general conclusions may be drawn:

1. The 1-10-15 G-A-W ratio is apparently best suited for the oil-free, acid-treated castors. Waximum yield 57.7\% fatty acid reduction.)

2. The 3-1-1.6 G-A-W ratio apparently gives best results with the dilute sulfuric acid-treated Ricinus Largus 
castors containing their original oil content. WWaximum yield obtained: $51 \%$ )

3. Iilerck's Pancreatin powder apparently works best with a 2-6-1 G-A-W ratio using five to ten grams pancreatin powder. (Naximum yield obtained:57\%)

4. The $3-1-1.6 \mathrm{G}-\mathrm{A}-\mathrm{W}$ ratio works favorably with Twitchell's Naphthalenestearosulfonic acia ("synthetic lipase") (Naximum reduction: $32 \%$ )

5. A $37 \%$ yield is the best obtainable with mixed variety castors both acetic and sulfuric acid-treated.

In several substrates which were submitted for confirmation of the esterification produced and for the determination of the type of glyceride formed, results of the vevoe and haynolds Research Laboratory indicated that in those substrates used for analysis, esterification had taken place and that a monoglyceride had apparently been formed.

l'hus, the results of this present work indicate that esterification of glyceriaes by enzymatic catalysis is possible in vitro if the proper ratio of substrate components is used. No set rules however may necessarily be applied in order to calculate the best ratio to use for maximum results by each type of enzyme preparation. In summary thenefore, it has been found in this work:

1. Using Iinseed oil fatty acias and glycerol, glycerides have apparently been synthesized through the enzymatic catalysis of lipase from Pancreatin powder (iverck) and of lipase liberated by dilute acid treatment of castor beans. 
2. Naphthalenestearosulfonic acid will also catalyze this synthesis.

3. Hach different catalyst requires a definite $G-A-W$ ratio in order for synthesis to occur.

4. water up to a certain amount may be present in these synthetic reactions.

5. Lastor beans may be used with or without their original oil content if treated first with dilute acid to Iiberate the catalyst. 
TABLE VI

HFHLCT UF VARIOUS AWOUNTS OH WATER ON

A SUBSIRAIE OF GLYCDROL-HAIIY ACID (LINSHED OIL) RAIIO OF 1-IO

\begin{tabular}{|c|c|c|c|c|c|c|}
\hline $\begin{array}{l}\text { SUBSTRATE } \\
\text { RATIO } \\
\text { G A W } \\
\text { CC CC } \mathrm{CC}\end{array}$ & THENP & $\begin{array}{l}\text { FATTY } \\
\text { ACID } \\
\text { CONTENT } \\
\%\end{array}$ & $\begin{array}{c}\text { FAIIY } \\
\text { ACID } \\
\text { DECREASE }\end{array}$ & $\begin{array}{c}\text { PER } \\
\text { CENT } \\
\text { DECREASE }\end{array}$ & $\begin{array}{l}\text { PLVE' } \\
\text { DAYS }\end{array}$ & ENLYIVIE USLD \\
\hline $\begin{array}{l}12-120-0 \\
(1-10-0)\end{array}$ & $\begin{array}{l}30 \\
30 \\
30 \\
30\end{array}$ & $\begin{array}{l}83.0 \\
71.5 \\
72.5 \\
85.0\end{array}$ & $\begin{array}{c}- \\
11.5 \\
10.5 \\
-\end{array}$ & $\begin{array}{c}- \\
13.8 \\
12.6 \\
-\end{array}$ & $\begin{array}{l}0 \\
1 \\
2 \\
3\end{array}$ & $\begin{array}{l}5 \text { grams } \\
\text { oil-free } \\
\text { acetic acid- } \\
\text { treated } \\
\text { castor } \\
\text { powder } \\
\end{array}$ \\
\hline $\begin{array}{l}10-100-10 \\
(1-10-1)\end{array}$ & $\begin{array}{l}30 \\
30 \\
30 \\
30\end{array}$ & $\begin{array}{l}68.0 \\
65.5 \\
68.0 \\
69.5\end{array}$ & $\begin{array}{c}- \\
2.5 \\
0.0 \\
-\end{array}$ & $\begin{array}{c}- \\
3.6 \\
0.0 \\
-\end{array}$ & $\begin{array}{l}0 \\
1 \\
2 \\
3\end{array}$ & $\begin{array}{l}5 \text { grams } \\
\text { oil-free } \\
\text { acetic acid- } \\
\text { treated } \\
\text { castor } \\
\text { powder } \\
\end{array}$ \\
\hline $\begin{array}{r}8-80-40 \\
(1-10-5)\end{array}$ & $\begin{array}{l}30 \\
30 \\
30 \\
30\end{array}$ & $\begin{array}{l}54.5 \\
52.5 \\
53.5 \\
54.5\end{array}$ & $\begin{array}{l}- \\
2.0 \\
1.0 \\
0.0\end{array}$ & $\begin{array}{l}- \\
3.6 \\
1.8 \\
0.0\end{array}$ & $\begin{array}{l}0 \\
1 \\
2 \\
3\end{array}$ & $\begin{array}{l}5 \text { grams } \\
\text { oil-free } \\
\text { acetic acid- } \\
\text { treated } \\
\text { castor } \\
\text { powder } \\
\end{array}$ \\
\hline $\begin{array}{l}5-5 \theta-75 \\
(1-10-15)\end{array}$ & $\begin{array}{l}30 \\
30 \\
30 \\
30\end{array}$ & $\begin{array}{l}32.3 \\
31.2 \\
24.6 \\
20.6\end{array}$ & $\begin{array}{r}- \\
1.1 \\
7.7 \\
11.7\end{array}$ & $\begin{array}{c}- \\
3.4 \\
23.8 \\
36.2\end{array}$ & $\begin{array}{l}0 \\
1 \\
2 \\
3\end{array}$ & $\begin{array}{l}5 \text { grams } \\
\text { oil-free } \\
\text { acetic acid- } \\
\text { treated } \\
\text { castor } \\
\text { powder }\end{array}$ \\
\hline $\begin{array}{l}3.6-36-90 \\
(1-10-25)\end{array}$ & $\begin{array}{l}30 \\
50 \\
30 \\
30\end{array}$ & $\begin{array}{l}21.2 \\
19.2 \\
20.4 \\
20.4\end{array}$ & $\begin{array}{l}- \\
2.0 \\
0.8 \\
0.8\end{array}$ & $\begin{array}{l}- \\
9.4 \\
3.7 \\
3.7\end{array}$ & $\begin{array}{l}0 \\
1 \\
2 \\
3\end{array}$ & $\begin{array}{l}5 \text { grams } \\
\text { oil-free } \\
\text { acetic acid- } \\
\text { treated } \\
\text { castor } \\
\text { powder } \\
\end{array}$ \\
\hline $\begin{array}{l}2-20-100 \\
(1-10-50)\end{array}$ & $\begin{array}{l}30 \\
30 \\
30\end{array}$ & $\begin{array}{l}13.0 \\
14.5 \\
13.8\end{array}$ & $\begin{array}{l}- \\
-\end{array}$ & $\begin{array}{l}- \\
-\end{array}$ & $\begin{array}{l}0 \\
1 \\
2\end{array}$ & $\begin{array}{l}5 \text { grams } \\
\text { oil-free } \\
\text { acetic acid- } \\
\text { treated } \\
\text { castor owd. }\end{array}$ \\
\hline
\end{tabular}


TABIE VII

POSIIIVE RESULIS

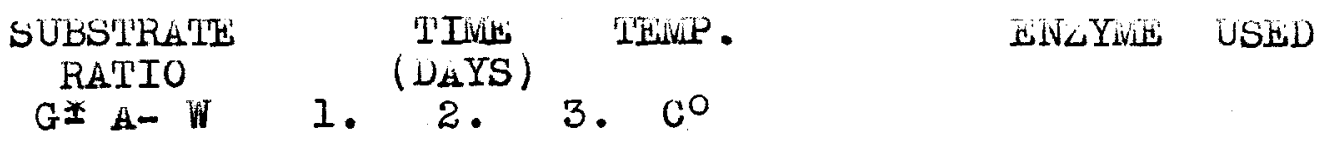

$3-1-1.6 \quad 25.5 \quad 55.6 \quad 80.5$

$2-6-1 \quad 46.255 .757 .1$

$2-6-1 \quad 30.550 .257 .3$

$\begin{array}{llll}1-10-15 & 10.4 & 33.9 & 57.7\end{array}$

$3-1-1.6$

$6-2-1$

$1-10-15$

$6-2-1$

$6-2-1$

$1-3-2$

$3-1-1.6$

$6-2-1$

$1-9-15$

$3-2-1$

$1-10-15$

1-10-0

$3-1-1.6$

$2-6-1$

$3-1-1.6$

$2-3-1$

$3-1-1.6$

$2-6-1$

$3-1-1.6$

$6-2-1$

$2-3-1$

3- $1-2$

$1-10-15$

$6-2-1$

$2-6-1$

$3-1-1.6$

$1-10-50$

$3-1-1.6$

$1-10-0$

$1-10-15$

2- 6-1

$2-6-1$

2- 3-1

3- 2-1

2- 6-1

2-6-1

$2-6-1$

$2-3-1$

$1-9-25$

$6-2-1$

$2-6-1$

$2-6-1$

$3-1-1.6$

$2-3-1$

$6-2-1$

$2-6-1$
$22.6 \quad 46.3 \quad 51.2$

$17.9 \quad 33.8 \quad 50.8$

$\begin{array}{llll}48.3 & 48.3 & 48.9\end{array}$

$18.0 \quad 38.3 \quad 47.5$

$47.147 .2 \quad 47.2$

$6.3 \quad 9.144 .9$

$39.139 .7 \quad 41.0$

$27.3 \quad 36.2 \quad 40.3$

- $\quad 1.640 .0$

$\begin{array}{llll}37.4 & 37.7 \quad 37.6\end{array}$

3.423 .836 .2

20.034 .936 .2

$24.2 \quad 34.4 \quad 35.2$

28.435 .2

$23.7 \quad 59.3 \quad 34.7$

20.450 .233 .3

$\begin{array}{llll}13.9 & 25.4 & 32.1\end{array}$

18.825 .031 .5

$14.2 \quad 23.4 \quad 30.1$

$10.8 \quad 22.9 \quad 30.1$

$24.3 \quad 28.3 \quad 29.7$

$25.2 \quad 22.4 \quad 29.6$

- 6.127 .1

14.121 .827 .0

11.119 .024 .7

$10.022 .1 \quad 24.5$

0.020 .124 .3

$9.6 \quad 15.5 \quad 24.4$

$5.811 .4 \quad 24.0$

- 16.523 .6

11.218 .321 .0

$6.814 .0 \quad 21.2$

10.918 .120 .5

$9.3 \quad 15.8 \quad 20.1$

5.211 .717 .6

$15.5 \quad 16.0 \quad 16.4$

7.412 .215 .9

$6.7 \quad 10.6 \quad 14.8$

4.26 .014 .2

$8.6 \quad 11.6 \quad 13.6$

$11.5 \quad 11.513 .1$

$13.0 \quad 13.0 \quad 13.0$

$4.9 \quad 9.4 \quad 12.5$

$4.3 \quad 7.7 \quad 11.3$

9.110 .111 .2

$4.17 .8 \quad 10.3$
28

30

50

30

30

$25 / 26$

30

50

25

30

30

$28 / 31$

39

30

30

29

30

30

30

30

30

30

30

$31 / 35$

30

30

30

29

30

30

30

30

30

40

30

30

32

30

30

30

30

30

39

30

$31 / 32128$

30

30

30

32

30 5g. Decorticated R.L.castors oil $\alpha_{2} \mathrm{H}_{2} \mathrm{SO}_{4}$

10g. Merck Pancreatin powder

$5 \mathrm{~g}$. Werck Pancreatin powder

lg. Uil-free, HAc castor powder

$5 \mathrm{~g} \cdot \mathrm{K} \cdot 2$.castors, $\mathrm{O} I \mathrm{~L} \& \mathrm{H}_{2} \mathrm{SO}_{4}$

$5 \mathrm{~g}$. Werck Pancreatin powder

lg. vil-free, HAc castor powder

$5 \mathrm{~g}$. werck Pancreatin powder

$13 \mathrm{~g}$. $\mathrm{R} . \mathrm{L}$. oil-free, $\mathrm{H}_{2} \mathrm{SO}_{4}$ castor powder

$5 \mathrm{~g} \cdot \mathrm{R} \cdot \mathrm{L}$. castors, oil, $\mathrm{H}_{2} \mathrm{SO}_{4}$

10g. Baker's K.L.castors, oif, $\mathrm{H}_{0} \mathrm{SO}_{4}$

5g. Decorticated R.Z.castors, oil, $\mathrm{H}_{2} \mathrm{SO}_{4}$

$5 g$. Werck Pancreatin powder

log. ivixed castors, oil, HAc

5g. Oil-free, HAc castor powder

3g.I.A.8G-Oil-free, HAc mixed castor pwd.

$5 g$. Gould Pancreatin powder

$5 \mathrm{~g}$. Baker's R.L.castors, oil, $\mathrm{H}_{2} \mathrm{SO}_{4}$

$5 \mathrm{~g}$. Wixed castors, $\mathrm{Oil}, \mathrm{H}_{2} \mathrm{SO}_{4}$

2g. Pfanstiehl steapsin powder(Iipase)

$5 \mathrm{~g}$. Naphthalenestearosulfonic acid.

10g. Gould Pancreatin powder

$5 \mathrm{~g}$. Naphth lenestearosulfonic acid.

$5 \mathrm{~g}$. Werck -ancreatin powder

log. mixed castors, oil, $\mathrm{H}_{2} \mathrm{SO}_{4}$

5g. Uil-free, HAc castor powder

$5 \mathrm{~g}$. Uil-free, HAc castor powder

$5 \mathrm{~g} \cdot \mathrm{K} \cdot \mathrm{Z}$. castors, $\mathrm{Oil}, \mathrm{H}_{2} \mathrm{SO}_{4}$

$5 \mathrm{~g}$. Nerck Pancreatin powder

log. Gould rancreatin powder

5g. Oil-free, Hac castor powder

$5 \mathrm{~g}$. Merck Pancreatin fowder

5g. Wixed castors, oil, Hac

$5 \mathrm{~g}$. Werck Pancreatin powder

$10 \mathrm{~g}$. Gould Pancreatin powder

$5 \mathrm{~g}$ - Naphthalenestearosulfonic acid

$5 \mathrm{~g}$. R.Z. castors, oil, $\mathrm{H}_{2} \mathrm{SO}_{4}$

$5 \mathrm{~g}$. Merck Pancreatin powder

$5 \mathrm{~g}$. Naphthalenestearosulfonic acid

$5 \mathrm{~g}$ - Oil-free, HAc castór powder

$5 \mathrm{~g}$. Gould Pancreatin powder

$5 \mathrm{~g}$. Merck Pancreatin powder

$5 \mathrm{~g}$. Werck Pancreatin powder

$5 \mathrm{~g}$. Mixed castors, oil, $\mathrm{H}_{2} \mathrm{SO}_{4}$

10g. Mixed castors, oil, $\mathrm{H}_{2} \mathrm{SO}_{4}$

log. Naphthalenestearosulfonic acid

5g. Uil-free, Hac castor powder

$5 \mathrm{~g} \cdot \mathrm{R} \cdot \mathrm{Z}$. castors, $\mathrm{Oil}, \mathrm{H}_{2 \mathrm{SO}_{4}}$

lg. Merck Pancreatin powder 
30. 


\section{ENLYLATIC SYNIHESIS UH SUGAR ESTLHS \\ FRON DEXIROSE AND LINSHLD OIL FAITY ACIDS}


Having obtained more or less successful results in bringing about synthesis of glycerides through enzymatic catalysis, attention was now turned to the problem of getting linseed oil fatty acids to combine with derivatives of polyhydric alcohols by similar means.

It was felt at the beginning that definite conditions would have to be worked out for this particular reaction through the use of the exploratory method, as was round necessary in the synthesis of glycerides, and that possibly an enzylie other than lipase may have to be employed.

wothing was found in the literature concerning any work like that contemplated. It was hoped however that information obtained from the glyeride studies would be of value for finding the proper ratio of substrate components in this present work. Lhere was some doubt nevertheless that previous work would be of any great value in this problem since actually this is an altogether different reaction. But insight gleaned from the work on glycerides did point more or less to the major factors which would most probably influence this reaction for obtaining maximurn synthesis or which might contribute to its inhibition.

In the present work the aextrose presented several probleins not encountered in the glyceride work. In the first place, the dextrose had to be dissolved and there arose the possibility that certain forms of it may react whereas others may not and thus the possible fiect of mutarotation and the time factor between solution of the dextrose and its use became involved. The possibility of fermentation of the dextrose presented another problem and of course the variation of dextrose concentration with respect to the other substrate components had to be considered. It was also 
much more difficult to obtain anä maintain an emulsion, even temporar1ly, in the present case compared to the experiments in which glycerol helped greatly to stabilize the substrate in this respect.

l'herefore, the present work posed many more problems and the mechanisin of this particular reaction becane more involved, more difficult to work with and less tangiole of accurate interpretation than the previous problem of glyceride synthesis.

several aifferent factors wich mignt possibly influence the reaction were stuaied simultaneously in many individual experiments. For example, the effect of water content, concentration of dextrose and fatty acids, temperature, whe order of adding components together in preparing the substrate, age of the dextrose solution, source end use of the enzyme, effect of stirring etc. were studied.

As a starting point, $G-A-h-$ (glycerol-fatty acias-water) ratios which had been used and which were found previously to give best results in the glyceride synthesis were used as standards with which to compare possible reactions of $\mathrm{D}-\mathrm{A}-\mathrm{W}$ (dextrosefatty acid-water) ratios of similar proportions and, using these, the effect of water content and variation of dextrose concentration was studied. Knowing the maximum yield of glyceride obtainable with Pancreatin powder, the blanks or controls of G-A-W substrates were run as a check to see if the enzyme preparation used each time was up to par.

the following pages describe typical experiments of comparative runs in these studies.

Lomparative runs were made using tive grams of werck's Pancreatin powder and a $1-9$ G-A ratio with variation of water 
content and similar substrates containing dextrose in the place of the glycerol. "Lhe " $\nu$ " in this series was a $90 \%$ aqueous solution of rfanstiehl dextrose (aissolved with the aid of heat). substrates were made so that the total volume was approximately the same in all cases even though substrate ratios were difierent. Dextrose was in excess of stoichiometric quantity in nurabers 7 , 8 and 9 , but stoichiometric proportions of dextrose and fatty acids existed in number 6 .

$\frac{\text { Substrate }}{\text { ratio }}$ Results after 3 days at $39^{\circ} \mathrm{C}$.

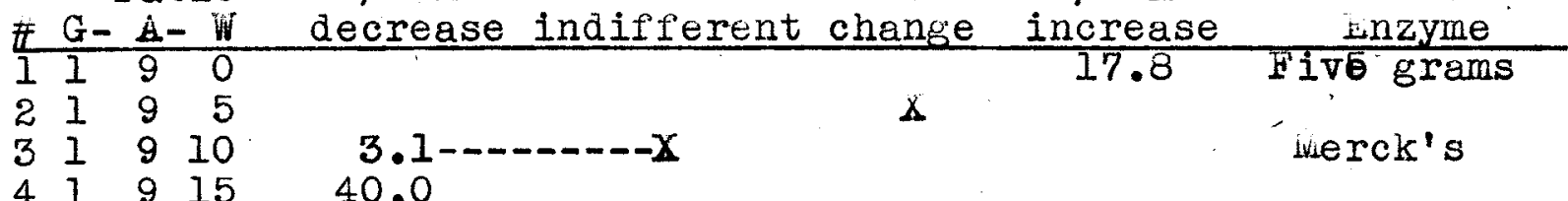

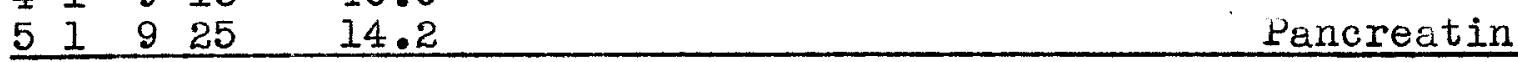

\begin{tabular}{ccccccc} 
& $G-$ & & & powder \\
\hline 6 & 0 & 9 & 5 & & 5.5 & \\
7 & 0 & 9 & 10 & $\frac{X}{X}$ & & used \\
8 & 0 & 9 & 15 & $X$ & \\
9 & 0 & 9 & 25 & in each
\end{tabular}

Upon addition of $25 \mathrm{ml}$ more of water to éach of numbers 6 , 7,8 and 9 there appeared no significant decrease after four more days of incubation ( $3.1 \%$ decrease only, in $\# 8)$. upon adaition of still more water and five grams more of pancreatin powder to each of numbers $1,6,7,8$ and 9 , no changes occured. after three days further incubation at $37-38^{\circ} \mathrm{C}$. except an apparent $22.8 \%$ decrease after two days in substrate number 1.

since accoraing to previous experiments with glyceride synthesis the 2-6-1 G-A-W ratio is apparently optimum for Pancreatin powder $157.3 \%$ reduction in fatty acids resulted in three days) this ratio was tried. Lxperiments employing both 90\% and $85 \%$ dextrose solution instead of the glycerol resulted in either indifferent or negative action. line order in wich the 
substrate components were daued together was also studied but no definitely positive results occured in any case. Lhis was equally as true when castors were used with optimun ratios. une exception occurea however in which 9 grams of fatty acids and ¿t ml of water containing 4 grams dextrose were incubated with R.c., $\mathrm{H}_{2} \mathrm{SO}_{4}$-treated castors at $30^{\circ} \mathrm{C}$. giving decreases of $3.3 \%$, $7.9 \%$ and $18.5 \%$ in 24,48 and 78 hours respectively.

It is obvious from the few experiments show above that such comparative runs gave quite erratic results insorar as the dextrose substrates were concerned.

From these and many other similar experiments in comparative studies concerning the substitution of dextrose in place of glycerol, the following conclusions were draw.

Using substrate ratios and enzyme preparations which were found in previous work to give optimum results with glycerol, results were mostly negative when dextrose was substituted for glycerol in the substrate. Furthermore, many such results were indifferent and many others even increased in acid number. Whe few results showing any appreciable reduction in acid number were not capable of being reproduced at this time.

In order to get satisfactory, temporary emulsions for obtaining homogeneous and representative aliquots for deternining the acid number every 24 hours, very concentrated solutions of dextrose were used in most cases. This may possibly have destroyed or denatured the enzyme by dehyaration. In most cases when dilute solutions of dextrose were used, homozeneous aliquots could not be obtained and results were therefore erratic. 
In view of the above results and conclusions, it was decided that the general method which was successful with glycerol was apparently not ideally applicable when dextrose was used.

It was felt that perhaps in order for optimum sugar ester synthesis to occur, the substrate components, i.e. dextrose and fatty acids, should be in closer contact with each other.

In looking back over the literature of fat and ester synthesis by enzymes it was tound that in several cases organic solvents were used as inutual solvents for the substrate components apparently with good results. $(39-48)$

One noteworthy example of these organic solvent suostrates is the use of acetone. It is claimed that lipase for example will work in an acetone medium if a certain amount of water is present. In accordance with this idea, proportions were worked out for acetone and water which would hold in solution both fatty acids and dextrose of aporoxinate molarity. Whis therefore oftered one possibility for the enzymatic synthesis of dextrose with linseed oil latty acids if the proper enzyme could be found to catalyze the reaction.

another example of the use of an organic solvent in this work is that of sym. ivany esters are reported having been synthesized by this method. Rona and co-workers have even claimed to have synthesized wax (cetyl palmitate) by using this technique. In the case of the problem at hand, using the method of sym, the fatty acias could be in solution in benzene or a similar solvent ana the dextrose could be in solution along with the enzyme in the aqueous phase. sym claims that synthesis takes place in the vater of imbibition of the enzyme which concentrates itself in the qqueous phase near the phase interface. The proauct of the reaction is 
removed as soon as it forms by reason of its solubility in the organic solvent thus removing it from the site of synthesis. The acid number of the organic solvent is measured to follow the extent of synthesis. The organic solvent thus acts as a reservoir for the fatty acids ana also removes the reaction product from the place of formation thus causing the reaction to proceed forward. In the present case, any concentration of dextrose could be used which would not interfere with the action of the enzyine.

It was felt however that perhaps an acetone solution containing both the fatty acids and the alcohol (glycerol) or the polyhydric alcohol derivative, together with rancreatin, might be an ideal way to bring the active substrate components into more intimate contact in a homogeneous manner, therefore this was tried first.

Proportions were worked out to acertain first the amount of water that could be added to a solution of fatty acids in acetone and still retain a clear solution. When the amount of either glycerol or dextrose that could be dissolved in this dilute acetone solution of ratty acids was determined for various concentrations of fatty acids.

Ihese results were then made into graphs and frorn the curves obtained, proportions were found in which a stable, clear, apparently true solution of dilute acetone resulted containing glycerol and fatty acids or aextrose and fatty acids in concentrations of similar molarity.

In one experiment for example, the substrate contained $0.3 \mathrm{k}$ fatty acids and 0.2 dextrose in acetone containing the maximurn amount of water. wuch substrates were run containing various amounts of Pancreatin powder(0.Ig .,0.2g.,0.5g.,2.0g•,3.0g•,5.0g.). 
Results of these however were negative and increases in acid number occured in some cases.

In another experiment, the substrate contained a solution of 0.55 in fatty acids and $0.55 \mathrm{l}$ glycerol in acetone containing its naximum content of water.to maintain solution. several such substrates were run at the same time each containing a different amount of Pancreatin powder $(0.1 \mathrm{~g} \cdot, 0.2 \mathrm{~g} \cdot, 0.5 \mathrm{~g} \cdot, 1.0 \mathrm{~g} \cdot$, $2.0 \mathrm{~g} \cdot, 3.0 \mathrm{~g} \cdot, 5.0 \mathrm{~g} \cdot, 10.0 \mathrm{~g} \cdot)$. All of these were negative except the one containing $10.0 \mathrm{~g}$. Pancreatin. In this particular case, a reauction of $17.6 \%$ of free fatty acids resulted in 24 hours and in 48 hours a free fatty acid reduction of $22.2 \%$ occured. Ihe substrate in this case was prepared as follows. To $8.1 \mathrm{ml}$ of a dilute glyeerol solution $(8 \mathrm{~g}$. glycerol aissolved in $75 \mathrm{ml}$ of water resulting in a total volume of $81.0 \mathrm{ml}$ ) $10 \mathrm{~g}$. of Pancreatin powder were ddded and allowed to stand overnight at $37^{\circ} \mathrm{C}$. To this was added $25 \mathrm{ml}$ of acetone-solution of fatty acids $124.5 \mathrm{~g}$. Iinseed oil latty acids ailuted up to z50 ml with acetone) 'The whole was then mixed until a hornogeneous solution resulted. Whis was then stirred in a water bath kept at a constant temperature of $37^{\circ} \mathrm{C}$. Whe final substrate contained $25 \mathrm{ml}$ iatty acids in acetone $(0.35 \mathrm{M}), 7.5 \mathrm{ml}$ water and $0.8 \mathrm{mI}$ glycerol $(0.35 \mathrm{lw})$. It is conceivable that this substrate could be improved upon by employing a glycerol extract of Pancreatin instead of using Pancreatin powder which gets quite voluminous when large quantities are ermployed. sttempts were now made to utilize the method of sym in the present problem. Preliminary experiments were run accoraing to the technique of sym (39-44) using Pancreatin powder, castor bean lipase and various alcohols and acids such as butyl alcohol, 
glycerol,oleic acid and benzoic acid in benzene-water substrates. sodium glycocholate was also used in addition in a few instances. un the whole, only a few slightly positive results were obtained.

In a similar setup using dextrose, linseed oil fatty acids and Pancreatin powder in benzene-water substrate, a slight increase in acid number was noted.

using glycerol and linseed oil fatty acids, some positive results were obtained employing the method of sym as is shown in the following examples.

In one case, 25 grams of linseed fatty acids were ailuted to $75 \mathrm{ml}$ with benzene and to this was added 15 grams of a glycerol extract of rancreatin containing $3 \mathrm{ml}$ of $30 \%$ sodium glycocholate and $3 \mathrm{ml}$ of $10 \%$ sodium acetate. Lhis was kept at $300 \mathrm{l}$. not stirred. A free fatty acid decrease of $1.7 \%$ resulted in one day, $3.8 \%$ in two days and $3.8 \%$ in three days.

In another case, a setup containing 14 grams linseed fatty acids diluted to bo $\mathrm{ml}$ with benzene, $30 \mathrm{ml} 10 \%$ sodiurn acetate, 2 grams Pencreatin powder, 4.6 grams glycerol and $2 \mathrm{ml}$ of $50 \%$ sodium glycocholate kept at a constant temperature of $37^{\circ} \mathrm{G}$. and not stirred, resulted in a free fatty acid reduction of $6.0 \%$, $7.3 \%$ and $12.6 \%$ in one, two and three days respectively. under similar conditions a $15 \mathrm{ml}$ glycerol extract of Pancreatin, $3 \mathrm{ml}$ of sodiun glycocholate and $30 \mathrm{ml}$ oleic acid kept at $37^{\circ} \mathrm{C}$. not stirred yielded reauction of $4.4 \%, 7.6 \%$ and 11.8\% after one, two end three days incubation.

However, in further similar experiments using the sym technique, most of the results were practically nesative or indifferent when glycerol and linseed oil fatty acids were used 
in benzene-water substrates with Pancreatin. uptimum as weIl as stoichiometric ratios were used in these cases. 'the only positive result of interest here was one which contained $112.5 \mathrm{ml}$ of water, 4.0 grams dextrose, 10 grams Pancreatin powder, $40.5 \mathrm{ml}$ linseed 0 il fatty acids and $100 \mathrm{ml}$ benzene. I'his resulted in a tatty acid decrease in one day of $1.5 \%$ of the original fatty acids present and $17.1^{\prime}$ after two days. It is also of interest to note that in anotiner set of substrates which contained to grans hog intestine ground with sand in a mortar, $: 0 \mathrm{~mL}$ glycerol, $15 \mathrm{ml}$ water and $90 \mathrm{ml}$ linseed oil fatty acids, results were indifferent in the presence of $5 \mathrm{ml}$ of ox bile but were positive in absence of bile to the extent of $5.5 \%$ fatty acid decrease in one day and $17.3 \%$ after two days.

It was deciaed at this time to go back and try to improve upon the original method using an aqueous solution of dextrose together with linseed oil fatty acids and to employ the idea of sym to this by not stirring the two phases except when aliquots were taken for determination of the acia number. Results of these and previous experiments revealed that apparently optimum conditions woula exist if the substrate contained 4 grams dextrose dissolved in $112.5 \mathrm{ml}$ water with 10 grams Pancreatin powder and $40.5 \mathrm{ml}$ linseed oil fatty acids added and the whole kept at a constant temperature of $30^{\circ} \mathrm{C}$ and not stirred. similar specimens prepared at the same time but kept at constant tenperature of $s 4.50 \mathrm{C}$. and others which were stirred all gave negative results. Uther similar experiments in which $90 \%$ dextrose solution was used yielded negative results.

Results of the optimum conditions in these experiments were 
as follows:

$\begin{array}{ccc}\text { days } \% \text { free acids reduced } & \text { acid number } \\ 0 & -- & 23.9 \\ 1 & 6.7 & 22.3 \\ 2 & 15.5 & 20.2 \\ 3 & 17.2 & 17.8\end{array}$

Results of further experiments of the kind just described yielded similar conclusions. Hore specifically, the best results were given by the following conditions. Io $112.5 \mathrm{ml}$ water dissolve 4 grams dextrose. uverlay this solution inmediately with 10 grams Pancreatin powder and allow to stand until the powder wets and sinks to the bottom of the flask. Shake well until a good emulsion results. Allow to stand two hours. Ihen add 40.5 ml fatty acids. Wix well and take aliquot immediately for acid number determination. Allow to stand without stirring at a temperature of $30^{\circ} \mathrm{C}$. The following results show the more positive yield thus obtained.

$\begin{array}{ccc}\text { days } y \text { decrease free fatty acids } & \text { acid number } \\ 0 & -- & 24.4 \\ 1 & 3.3 & 23.6 \\ 2 & 23.3 & 18.7 \\ 3 & 27.5 & 17.7\end{array}$

In similar substrates, when $\mathrm{H}_{2} \mathrm{SO}_{4}$-treated castors containing their original oil content were used instead of Pancreatin, unstable emulsions resulted and results were inaifferent. An attempt was made to acertain the effect of temperature on the substrates containing Fancreatin. None of these substrates were stirred. One was kept at room temperature, one at $37^{\circ} \mathrm{C}$. and one was refriserated at $8^{\circ} \mathrm{C}$. Hach substrate resulted in a milky emulsion. Lach contained ll2.5 ml linseed oil fatty acids 
$112.5 \mathrm{ml}$ water, 10 grams Pancreatin powder and 4 grams dextrose added together in the order: water, dextrose, pancreatin, fatty acids.

Percentage decrease of original free fatty acids resulted as follows:

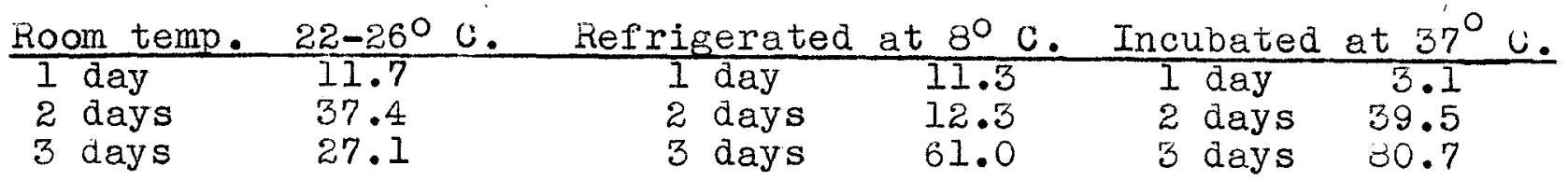

Results were negative at $23-240 \mathrm{C}$. using $100 \mathrm{ml}$ water, 5 grams dextrose, 35 grams fatty acids and 10 grams rancreatin powder.

Experiments in which formalin was used in an attempt to prevent fermentation yielded results which were inconclusive. epparently anything that might hinder or prevent the fermentation also hindered or prevented the enzyme action.

A very troublesome problem presented itself when, in following the same procedure in which positive results were obtained, the results would be negative. In other words, in most cases, positive results could not always be duplicated. Ihis led to the belief that perhaps some action in the preparation of some of the substrates wo overlooked as to its importance in effecting the reaction and was therefore not noted in the directions for preparation. Therefore, in still another attempt to get more information concerning this, a series of experiments was run to acertain the effect of the concentration of Pancreatin to use, the advisability of hydrating the Pancreatin before use, the effect of various amounts of formalin on the reaction and on fermentation, the effect of temperature and the effect of mutarotation of the dextrose solution as well as the effect of the order of adding the substrate components. It was believed the latter two effects 
were most important. The following results represent typical experiments in which the above effects were studied.

Hach substrate contained $112.5 \mathrm{ml}$ of water, 4.0 grams of C.P. dextrose, 10 grams Pancreatin powder and $40.5 \mathrm{ml}$ of $1 \mathrm{in}-$ seed oil fatty acids. All substrates were kept at room temperature (230) and none were stirred. In this series, each of the seven substrates was treated in a different way as follows:

1. All components were added together immediately and the Pancreatin was not hydrated before use.

2. The dextrose solution was incubated overnight and the Pancreatin powder and fatty acids were then added.

3. The dextrose and the Pancreatin powder were incubated together overnight and the fatty acids were then added.

4. 'The dextrose solution was incubated overnight, the Pancreatin powder was hydrated before use and the fatty acids and formalin were finally added.

5. I'he Pancreatin powder was first hydrated and was then incubated together with the dextrose overnight. Fatty acids and formalin were then added.

6. The Pancreatin powder was first hydrated. ihe other components (dextrose and fatty acids) were then added and the substrate was kept at room temperature $(230 \mathrm{C.})$

7. Whe dextrose solution was incubated overnight at $25^{\circ} \mathrm{C}$. (instead of the incubation temperature of $37^{\circ} \mathrm{C}$. that was employed in all of the other substrate prepatations.. Pancreatin powder and fatty acids were then added.

Results of this series were either negative or erratic, e.g. number 7, after a rise, gave $18.5 \%$ decrease the third day.

In another series prepared in the same way as that described above but run for a longer time, the results were generally negative or indifferent with increases resulting the first three days and subsequent decreases in acid values in numbers 2,3 and 4 of about $9 \%$ the fourth and fifth days. 'lhose substrates showing more positive results were as follows: 


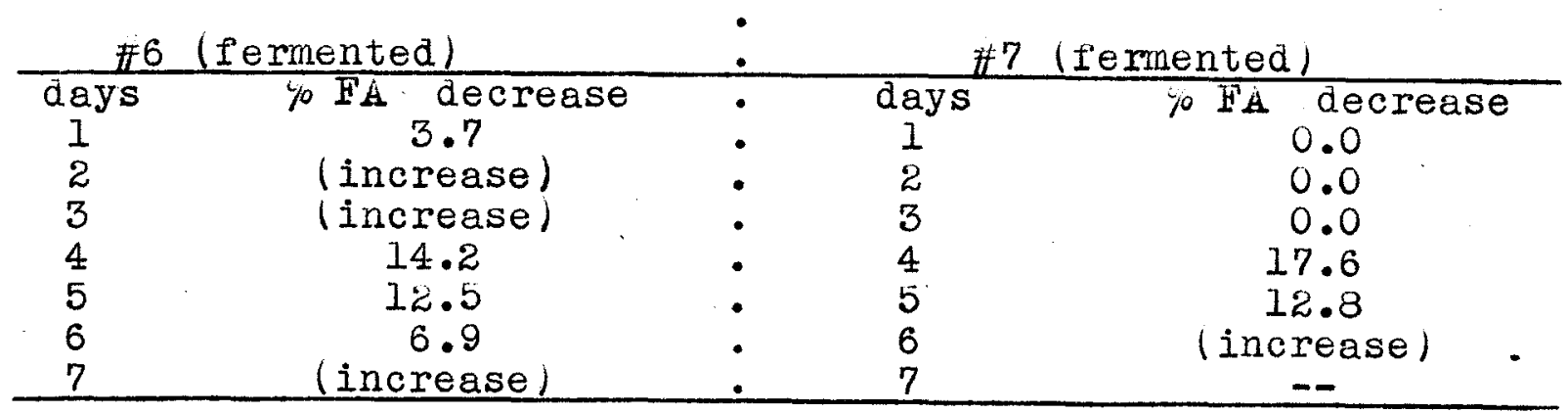

In view of the results obtained in experiments such as those described above, it was Iinally concluded that the approach just elaborated did not yield accurate information concerning the various effects which were found necessary to be studied.

In order to acertain the possible effect of mutarotation of the dextrsoe upon the reaction, a series of substrates was set up which yielded the following results:

\begin{tabular}{|c|c|c|c|c|}
\hline substrate days & je & yo & days & substrate \\
\hline $\begin{array}{ll}\text { l.dextrose diss- } & \text { I } \\
\text { olved in water. } & 2 \\
\text { wetted pancreatin } & 3 \\
\text { added immediately. } & 4 \\
\text { latty acids added.I7 }\end{array}$ & $\begin{array}{l}-7.2 \\
-13.5 \\
+3.9 \\
+1.9 \\
-26.7\end{array}$ & $\begin{array}{l}-4.6 \\
-20.5 \\
-0.9 \\
---\overline{-} \\
-30.7\end{array}$ & $\begin{array}{r}1 \\
2 \\
3 \\
4 \\
17\end{array}$ & $\begin{array}{l}\text { 7. Lextrose dissolved } \\
\text { in water.stood } 29 \text { hrs } \\
\text { at } 25^{\circ} \text { c. Pancreatin } \\
\text { and fatty acids then } \\
\text { added. }\end{array}$ \\
\hline $\begin{array}{lr}\text { 2. Dextrose in } & 1 \\
\text { wtter.jtood } 2 \text { hrs. } & 2 \\
\text { at } 37 \text { o. Hatty }^{2} & 3 \\
\text { acids added. } & 4 \\
\text { (fermented) } & 17 \\
\end{array}$ & $\begin{array}{l}+8.1 \\
+3.0 \\
-20.0 \\
+4.0 \\
-9.0 \\
\end{array}$ & $\begin{array}{l}+4.6 \\
+7.7 \\
+1.9 \\
+9.1 \\
\end{array}$ & $\begin{array}{r}1 \\
2 \\
5 \\
4 \\
17 \\
\end{array}$ & $\begin{array}{l}\text { 8. Dextrose in water. } \\
\text { Pancreatin added } \\
\text { immediately.stood } 2 \\
\text { hrs.at } 29^{\circ} \mathrm{C} \text {. Hatty } \\
\text { acids then added. }\end{array}$ \\
\hline $\begin{array}{ll}\text { 3. vextrose in } & 1 \\
\text { water stood } 4 \text { hrs } 2 \\
\text { at } 370_{0} \text {. Pan- } & 3 \\
\text { creatin and fatty } 4 \\
\text { acids added. (fer) } 17\end{array}$ & $\begin{array}{r}+2.4 \\
-2.9 \\
0.0 \\
+\quad 2.9 \\
-33.3 \\
\end{array}$ & $\begin{array}{l}-5.5 \\
-9.4 \\
-11.9 \\
-17.0 \\
-33.9\end{array}$ & $\begin{array}{r}1 \\
2 \\
3 \\
4 \\
17 \\
\end{array}$ & $\begin{array}{l}\text { 9.water, flycerol and } \\
\text { Pancreatin added to- } \\
\text { gether.stood } 15 \text { min. } \\
\text { Fatty acids added. } \\
\text { Gaw ratio } 30-90-15 \text {. }\end{array}$ \\
\hline $\begin{array}{lr}\text { 4. Dextrose in } & 1 \\
\text { water stood } 6 \text { hrs } & 2 \\
\text { at } 370 \text {. Pancre- } & 3 \\
\text { atin and fatty } & 4 \\
\text { acids added.(fer) } & 17 \\
\end{array}$ & $\begin{array}{l}+0.4 \\
+3.7 \\
-6.0 \\
+3.7 \\
-26.0\end{array}$ & $\begin{array}{l}71.6 \\
f 1.6 \\
f 1.4 \\
-2.7 \\
---\end{array}$ & $\begin{array}{r}1 \\
2 \\
3 \\
4 \\
17 \\
\end{array}$ & $\begin{array}{l}\text { 10. Dextrose in water } \\
\text { stood } 29 \text { hrs at } 37{ }^{\circ} \\
\text { Pancreatin and fatty } \\
\text { acids then added. }\end{array}$ \\
\hline $\begin{array}{ll}5 . \text { vextrose in } & 1 \\
\text { water.stood } 8 \text { hrs } & 2 \\
\text { at } 370 \text {.Pancreatin } & 3 \\
\text { and fatty acids } & 4 \\
\text { then added. } & 17 \\
\end{array}$ & $\begin{array}{l}71.9 \\
+2.4 \\
-1.9 \\
+5.2 \\
-9.7 \\
\end{array}$ & $\begin{array}{l}t 4.8 \\
t \quad 3.2 \\
+\quad 3.8 \\
-7.9 \\
-.-1 \\
\end{array}$ & $\begin{array}{r}1 \\
2 \\
3 \\
4 \\
17 \\
\end{array}$ & 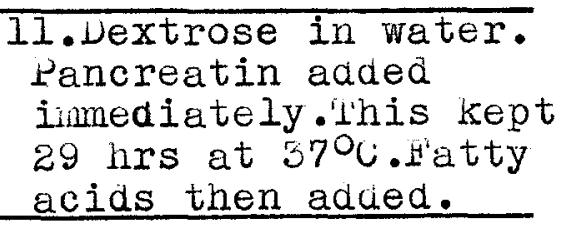 \\
\hline $\begin{array}{lr}6 . \text { Jextrose in } & 1 \\
\text { water.stood } 21 \text { hrs } & 2 \\
\text { at } 370 \text {. Pancreatin } & 3 \\
\text { and fatty acids } & 4 \\
\text { then adaed. } & 17 \\
\end{array}$ & $\begin{array}{r}+0.9 \\
+1.9 \\
+6.8 \\
--- \\
-39.2 \\
\end{array}$ & & & \\
\hline
\end{tabular}


In order to check the potency of the rancreatin oowder used in the above experiment, substrate number 9 was repeated using fresh rancreatin powder. Results revealed the following yield:

\begin{tabular}{cc} 
days & \% F decrease \\
\hline 1 & 9.8 \\
2 & 17.9 \\
3 & 24.7 \\
4 & 28.3 \\
17 & 38.2
\end{tabular}

I'he freshness of the Pancreatin powder employed in the subsequent series was assured by checking its potency in a similar way each time before it was used.

Since aifferent sources of dextrose were used in the various experiments, the following series was run in order to determine whether or not dextrose of different purity or whether or not dextrose from the different sources might effect the extent of the reaction. Information from previous experiments was used in order to prepare the best possible substrate for this series.

T' $112.5 \mathrm{ml}$ of distilled water (armonia-free, rermutitireated) 4 grams of dextrose was added. As soon as it was dissolved, 10.0 grams of fresh, Werck's Pancreatin powder was added. This was allowed to stand (Pancreatin floating on the solution) until it was wetted and sank to the bottom of the solution. It was then mixed thoroughly and $40.5 \mathrm{ml}$ of freshly distilled linseed oil fatty acids were added gradually with constant stirring. This mixture was then mixed thoroughly and a $2.0 \mathrm{ml}$ aliquat was removed and accurately weighed, dissolved in $10 \mathrm{ml}$ of $1 \%$ alcoholic phenolphthalein and titrated with $0.1 \mathrm{~N}$ aqueous $\mathrm{NaOH}$. 
'he substrate was kept at a constant temperature and was not stirred except just before an aliquot was taken for fatty acid determination after each 24 hours.

Using Pfanstiehl dextrose the results were as follows:

liemp. C.0 \% fatty acid decrease Remarks

24 hrs. 48 hrs. 72 hrs.

$\begin{array}{crrrl}37 & 5.2 & 30.0 & 24.9 & \text { No fermentation } \\ 8 & 10.4 & 28.0 & 48.4 & \text { No fermentation } \\ 25 & 2.9 & 7.9 & 0.5 & \text { Fermented } \\ 25 / 26 & 2.4 & 2.4 & 2.8 & \text { Fermented }\end{array}$

Using "C.P." dextrose the results were as follows:

$\begin{array}{rrrrl}37 & 4.8 & 32.4 & 28.7 & \text { slight fermentation } \\ 8 & 65.0 & 35.2 & 24.8 & \text { No fermentation } \\ 25 & 2.8 & 2.3 & 5.1 & \text { slight fermentation }\end{array}$

In a similar substrate using 4 Erams tastman anhydrous dextrose in $112.5 \mathrm{ml}$ of plain aistilled water with 10 grams fresh, werck Pancreatin powder and $40.5 \mathrm{ml}$ of linseed oil fatty acids, each cpmponent added immediately one after the other and shaken thoroughly after each addition and this substrate mixture not stirred, the following results were noted:

days $\% \mathrm{HA}$ decrease $(80 \mathrm{C}) \.% \mathrm{HA}$ decrease $\left(37^{\circ} \mathrm{C}\right) \% \mathrm{H}^{\mathrm{A}}$ decrease(boiled)

$\begin{array}{llll}1 & -2.9 & +5.7 & \neq 2.0 \\ 2 & -17.3 & +2.8 & \neq 0.8 \\ 3 & -41.3 & +3.3 & \neq 4.8 \\ 4 & -30.7 & -4.7 & +3.2\end{array}$

after due consideration of the data obtained in all of the experimental work done on the present problem, it was felt that probably there might be two aifierent reactions progressing at the same time in the same substrate, each one perhaps progressing at a different rate according to the existing conditions.

It was thought that possibly one of these reactions was a fermentation reaction in which organic acids were being formed, as evidenced in some instances by an increase in the acid number 
over that originally present in the substrate and also as evidenced in other cases where the acid number increased again after an initial decrease.

Whe other reaction, progressin at the same time in the same substrate, was hoped to be one of synthesis in which the fatty acids of the substrate were combining in some way with the dextrose, thus giving a gradual aecrease in acid number. It was considered likely that in the light of the above possibilities, the apparently slight decreases in acid number in many cases may possibly have been oversha dowed by a counter increase in acids from fermentation and that in many instances the actual total extent of synthesis might have been underestimated since the acid number was the only criterion of measurement concerning the extent of synthesis in these experiments.

Further experiments were therefore planned in an attempt to determine whether or not two reactions were operating simultaneously in this system and at the same time to obtain more specific information concerning the effect of pri, temperature etc. Insofar as these are concerned in the control of each reaction with the hope that optimum conditions might be worked out whereby a maximum,progressive decrease in acid number would be obtained while at the same time the fermentation reaction would be supressed and held at a minimum.

Attempts were made at first to determine the acid number of the aqueous phase each 24 hours inorder to acertain the extent of organic acids formed from fermentation. It was found however that most of the substrate when mixed thoroughly gave temporary emulsions which could not always be sharply and uniformly separated into aqueous and non-aqueous phases and therefore consistant 
results were not obtainable. By aadition of sodium bicarbonate or phosphate buffers it was thought possible that any organic acids formed might be neutralized as they were formed and thus give the synthesis reaction a better chance to proceed.

Results of this particular series of experiments are best shown and interpreted through the use of graphs.

In the first series, the following quantities of components were used: $112.5 \mathrm{ml}$ water, 4 grams dextrose, lo grams fancreatin powder, $40.5 \mathrm{ml}$ linseed oil Iatty acias and I gram sodium bicarbonate.

l'he acid number was determined every 24 hours in each of the following ditferent substrates.the substrate components in each case were adced in the order given.

1. water, dextrose, Pancreatin ana tatty acids.

2. water, dextrose, Pancreatin, $\mathrm{NaHiO}_{J_{5}}$ and fatty acids.

3. water ana Pancreatin.

4. water, dextrose anc pancreatin.

5 . water and dextrose.

a set of all ilve of these substrates was kept in three separate series of experiments at temperatures of $37 \mathrm{O}^{\mathrm{L}}$.(incubated) in one case, 250 . (room temperature) in another case and at $5^{\circ} \mathrm{c}$. (refrigerated) in siill another case.

Comparisons from the graphs (A) resulting from these data show that:

1. Whe acidity increase in the aqueous phase is apparently not due to fermentation of dextrose but rather to the fermentation of the hydrated Pancreatin powder.

2. Lower temperatures apparently favor the reaction of synthesis in the aqueous substrate. Hermentation was apparently diminished or checked unäer these conditions. 
3. Neutralizing the acidity of the Pancreatin before use, with sodium bicarbonate favors reduction of the acid number of the mixture and therefore it is apparently helpful for synthesis. In another series of experiments, a phosphate buffer of pir 7.5 was used in place of the water. the following quantities of components were used: $112.5 \mathrm{ml}$ phosphate buffer pi $7.5,4$ grams dextrose, 10 grams fancreatin powder, $4015 \mathrm{ml}$ linseed il fatty acids and 1 gram $\mathrm{NaHCO}_{3}$.

The acid number was determined separately every 24 hours in each of the following substrates. The components were added in the order given.

I. Buffer, dextrose, Pancreatin and fatty acids.

¿. Euffer, dextrose, rancreatin, $\mathrm{NaHCO}_{3}$ and fatty acids.

5. Buffer and Pancreatin.

4. buffer, dextrose and iancreatin.

5. Buffer and dextrose.

A set of each of these was kept in separate series at temperatures of $37^{\circ} \mathrm{C}, 2,27^{\circ} \mathrm{C}$. and $5^{\circ} \mathrm{C}$.

Comparison of tie graphs (B) resulting from these data show that:

1. Ihe dextrose does not ferment but the hyc pated Pancreatin does fement either by itself in the buffer or when dextrose is also adcied. Whe results of these two cases are practically parallel. 2. Higher temperature is apparently better suited for this buffered substrate.

3. Neutralizing the Pancreatin before use was also heloful in this medium for obtaining maximum acid number reduction. In a third series of experiments, phosphate bulfers of different ph values were employed and the acid number was run in duplicate in each case. 
Hach substrate of this series contained the following. 'The components were adaed in order given: $112.5 \mathrm{ml}$ phosphate buffer, 4 grams dextrose, 10 grams rancreatin powder and $40.5 \mathrm{ml}$ linseed oil fatty acids. all were kept at $37^{\circ} \mathrm{C}$.

Results as given in the graphs (C) revealea that apparently the reaction of synthesis may work best in a slightly alkaline medium. soaps formed may have had a catalytic effect in these instances.

Although. it was realized that a mixture of water and fatty acids alone would yfelo eratic results as far as acid numbers were concerned, due to the fact that a homogeneous aliguot could not be obtained, nevertheless, this mas attempted and results as shown in the graphs (D) indicate that consistant results were impossible to obtain. similar runs (E) using phosphate buffer of pH 7.5 yielded results which were not quite so erratic.

It is to be concluded then that two systens are progressing simultaneously in such substrates as those described above. Whis perhaps means then that the results as given previously represent somewhat conservative estimates as to the extent of synthesis.

concerning synthesis of sugar esters by enzymatic catalysis it may be said in sumnary thet attemps were made to apply techniques found previously to be successful for glyceride synthesis but results were erratic and not dependable. 'The use of the sym tebhnique and other methods in which organic solvents-water phases were employed also gave for the most part negative results. some apparently positive results were obtained by employing the aqueousfatty acid phase mixture under epecially developed, improved conditions. Various factors were studied concerning their et'tects on the synthesis but no particularly definite conclusions could be 
drawn since each factor is apparently interrelated with others and no one factor revealed any specific, favorable action to any great extent.

It was finally revealed that the pancreatin would ferment and form acids. un attempt was made to block this interference and some positive results resulted.

It is adnittea that this phase of the present work is incomplete insofar as an exaustive stuay is concernea but time has not permitted rurther work to be aone. Nesults obtained however do point the way to further approaches from which to launch further research into this most interesting and important field. 


\section{LEGEND FOR THE FOLLOWING SERTES OF GRAPHS}

In each case the abscissa is a measure of days incubation and the ordinate is a measure of the percentage of free fatty acids in the substrate mixture.

In Graphs $A$ and Graphs B:

Color Substrate content

water, dextrose, Pancreatin and fatty acids.

water, dextrose, Pancreatin, $\mathrm{NaHCO}_{3}$ and fatty acids.

water and Pancreatin.

water, dextrose and Pancreatin.

water and dextrose.

In Graphs C :

Average of duplicate runs of phosphate buffers of the $\mathrm{pH}$ indicated. All substrates kept at $37^{\circ} \mathrm{C}$.

In Graphs D:

Mixture of water and fatty acids kept at the temperature indicated.

In Graphs $\mathbb{E}$ :

Mixture of phosphate buffer of $\mathrm{pH} ~ 7.5$ and fatty acids kept at the temperature indicated. 


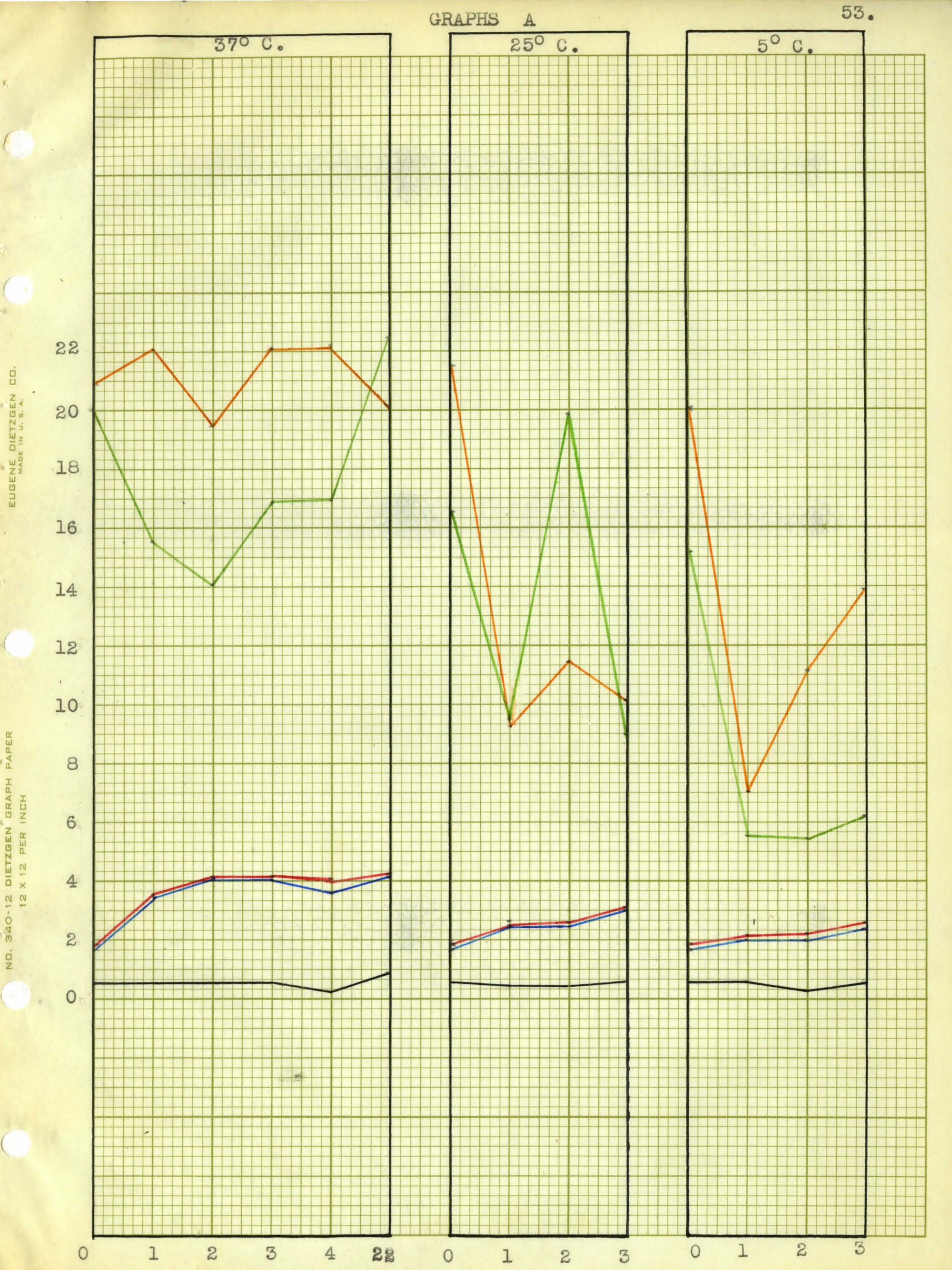




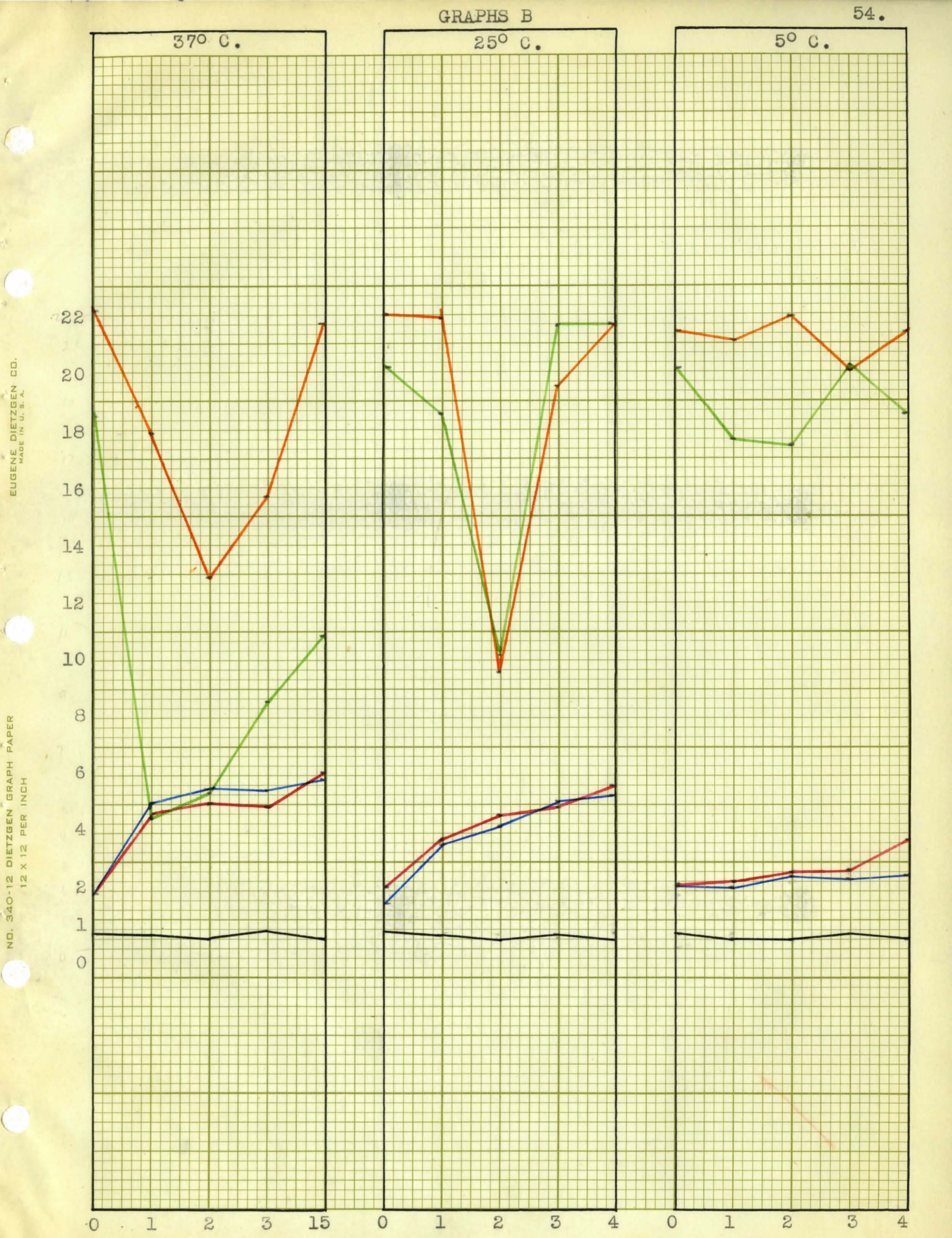


GRAPHS D

56.

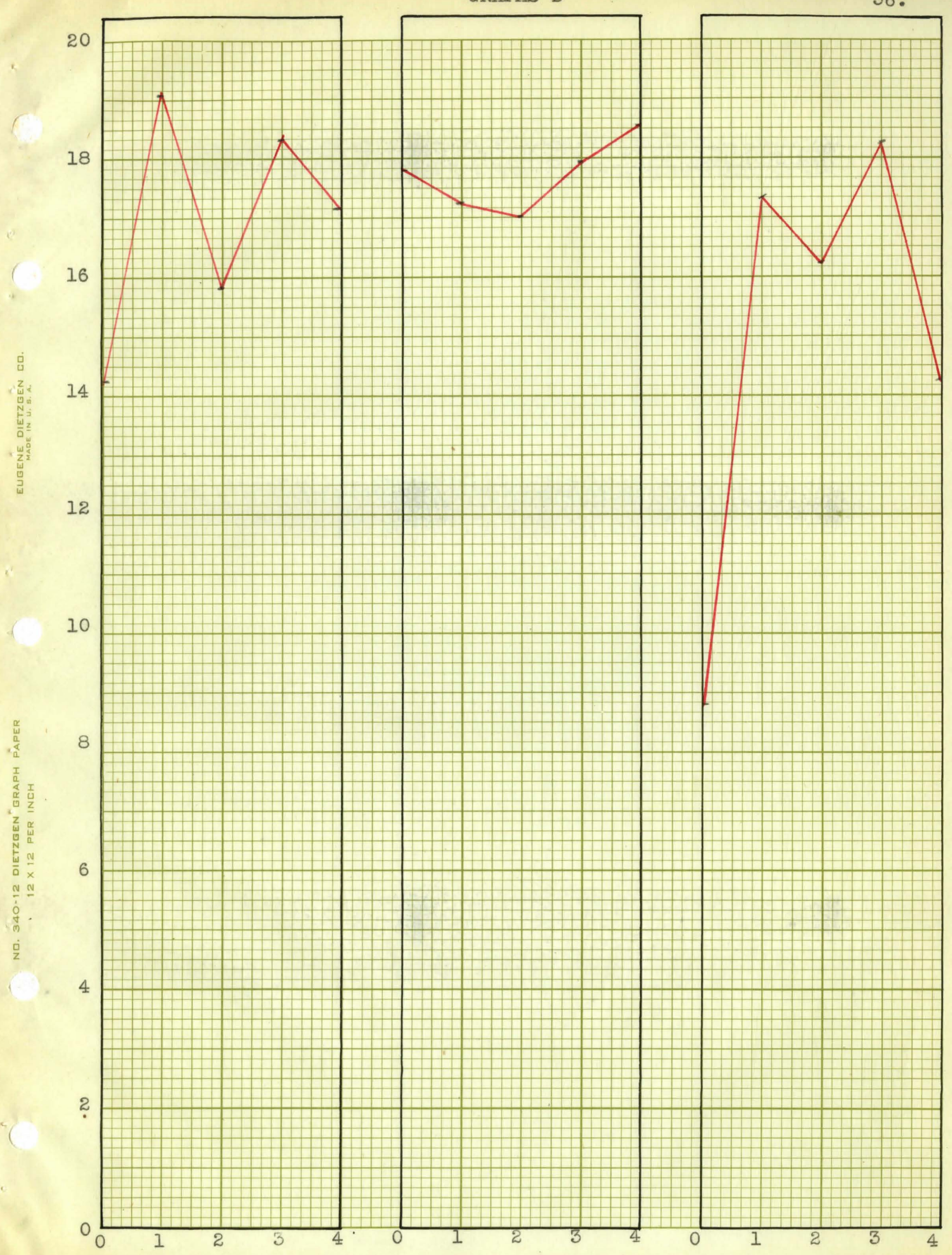


58. 
59.

GENERAL SUIVIARY AVD CONCLUSIONS 
It has been shown in recent years that reversible enzymatic reactions may be controlied so as to cause synthesis to predominate.

Due to the intangible and pioneering nature of the particular problems undertaken in the present work, the exploratory method of research was necessarily employed.

The various factors effecting the synthetic reactions studied have been dealt with in various ways and certain conclusions have been drawn concerning the importance of each factor in its relationship to the others.

It is felt by the writer that glyceride synthesis has been successfully accomplished to a much greater extent than that anticipated.

the work on sugar ester synthesis however has not been so fruitful, but this was rather expected when the writer was assigned this task. wuch intormation has been obtained however in this phase of the present work and it must be realized that in order to completely conquer this particular problem it would require much more time and more ingenious technique than was at the writer's disposal.

'this work as a whole is merely a small contribution to the vast lack of knowledge of such enzyme systems. It may be thought of merely as turning the feet to step in the right direction.

In this study of synthesis by enzymatic catalysis the literature has been reviewed and much invaluable information thus gained has led to insight of greater depth into the făcinating realm of enzymology.

Enzymology as it is reviewed by sumner and Sommers (39), Falk (40), Waldschmidt-Leitz and walton (4I) and Tauber $(42 ; 43$ ) 
opens a vast and fertile field for biochemical research. It no doubt will be the center of biochemical interest in the immediate years to come and it offers in its vastness and in its imortance a field so large as to offer great possibilities for research efforts for many years to come.

'the interrelationships between hydrolysis and synthesis in reversible enzymatic reactions and the important implications of glycolytic, proteolytic and lipolytic enzyme systems in their relationship to various other important enzyme systems is just now beginning to throw brighter light upon the intricate mechanisms involved in metabolism and catabolism of both normal and abnormal conditions.

the clinical use of such enzymes as acid and alkaline phosphatase, lipase, diastase and thrombin has already proven the value of enzyme studies in the diegnosis of pathological conditions and no doubt many more enzymes or enzyme systems will become of clinical value.

Enzyme studies will throw much light upon the cancer problem as the work of Potter and others have shown ana indeed in the final analysis the key to the solution of cancer cause and cure lies in the realm of enzymology.

enzymatic synthesis is now literaly growing by leaps and bounds in many phases of biochemical work. Hardly a month passes - ithout some reputable journal including another phase of this intrigueing work. Hor example, the recent work of lireen and stompf (44), Cori and Cori (45), Hidy and Lay (46), voudoroff (47) Colwick and southerland (48) and others has given impetus to polysacharide synthesis. 'The work of bermann and H'raenkel-Conrat (49) and others in protein synthesis also points to a general trend toward the reality and possible uses of enzymatic synthesis. 
'these findings as well as those in the making must eventually become of great importance to meaicine, to agriculture, to inaustry and perhaps to many other related fields. we now have a new era being ushered in betore us in the field of Biochemistry. It is the enzyme age in which these intangibles are becoming approachable by modern methods and techniques, an age which will necessarily influence the philosophy and approach of physiology and related fields as well as the field of Biochemistry and an age which will in the final analysis definitely effect our scientitic philosophy of life. itself and of the creator of all living things. 
63.

BIBLIOGRAPHY 


\section{REFERENCES CITED}

1. Tamman, G., ㄴ. Phýsik. Lhem., 16, 271, (1892).

2. Van't Hoff, J.H., L. anorg. (chem., 18, 1 (1898).

3. Tiauber, H., Enzyme Chemistry, John Wiley \& Sons, Inc., New York, p.22, (1937).

4. Hill, A.C., jo. 쓰. hem. Soc., 73, 634 (1898).

5. Hmerling, 0., Ber. Ghem. Ges., 34, 609,3810 (1901).

6. Bourquelot, ผ., and Bridel, M., compt. rend., 154, 944, $1375(1912)$.

7. salter, w.T., and Pearson, O.H., Jo. Biol. Ghem., 112,579 (1936).

8. wastneys, H., and Borsook, H., Physiol. Revs., 10, 110 (1930).

9. Bergmann, M., and Fraenkel-conrat, H., Jo. Biol. chem., Il9, $707(1937)$.

10. Kay, H.ע., biochem. Jo., 17, 277 (1923).

11. Hassid, W.L., Loudoroff, w., and Barker, H.A., Jo. m. chem. Soc., 66,1416 (1944).

12. Loudoroff, ir., Jo. Biol. Chem., 151, 351 (1943).

13. Hidy, P.H., and Day, H.G., Jo. Biol. Chem., 152, 477 and 479

(1944). See also Colwick, S.P., and southerland, L.w., Jo.

, Biol. Chem., 144, 483 (1942).

14. Sumner, J.B.and Somers, G.F., Chemistry and wethods of Enzymes, Academic Press Inc., New York, pp. 34-35, (1947).

15. Kastle, J.H., and Loevenhart, A.S., 쓰. hem. Soc. Jo., 24, 491 (1900).

16. Pottevin, H., Compt. rend., 138, 378 (1904).

17. Pottevin, i., Ann. del. Inst. Yasteur, 20, 901 (1905).

18. Bodenstein, iu., and Lietz, $w_{.}$, L. Electrochem., 12, 605 (1906).

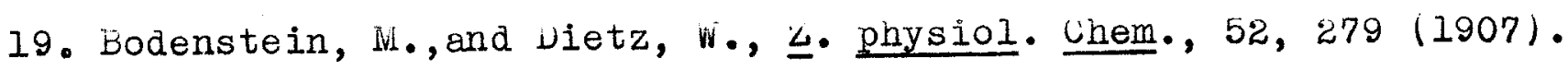


20. Hanriot, M., compt. rend., 132, 212 (1901).

21. Pottevin, H., Compt. rend., 136, 767 (1903).

22. Taylor, A.E., Jo. Biol. Shem., 2, 102 (1906).

23. Hamsik, A., ㄴ. physiol. Ghem., 59, 1 (1909).

24. Hainsik, A., L. physiol. chem., 71, 238 (1911).

25. Armstrong, H.E., Proc. Roy. Doc. London, B., 76, 606 (1905).

26. Taylor, A.H., Univ. 의 Gal. Pub. Pathol., I, 35 (1904).

27. 'Litchell, E., Jo. ㅆ․ (uhem. Doc., 29, 566 (1907).

28. Lunlap, H.L. and Gilbert, L.0., Jo. ㅆm. hem. poc.,Pt. 2, 1787 (1911).

29, welter, A., ‥ angew. Lhem., 24, 385 (1911).

30. welter, A., and Ivanov, N., see Leathes, J.B., and Raper, H.S., The Fats, Longmans, Green and Co., New York, 104 (1925).

31. armstrong, H.E., and Gosney, H.W., Proc. Roy. Soc. London, 88, B., 176 (1915).

32. Solander, Y.W., Biochem. ㄴ.., 36, 455 (1911).

33. Sym, i.A., Enzymologia, 1, 156 (1936).

34. Rona, P., Biochem. ‥, 249, 446 (1932).

35. Tanaka, Y., Jo. of $\mathrm{kol}$. of Engineering, lokyo Imperial University, $5,25(1910)$.

36. srmstrong, H.E. and Gosney, H.H., Proc. Roy. Soc.,B., 86, 588, (1913).

37. Lunlap, H.L.and Gilbert,L.0., op. cit.

38. armstrong, H.k. and Gosnay, H.W., op. cit. (1915).

39. sumner, J.B., and somers, G.F., op. cit.

40. Halk, K.G., The Chemistry of Enzyme actions, 'the Chemical Catalog co., Inc., Wew York (1924).

4l. Waldschmiat-Leitz, H., and walton, R.P., Enzyme Actions snd Properties, John Wiley and sons, Inc., New York (1929). 
42. 'l'auber, H., Hnzyme Chemistry, op cit.

43. 'Lauber, H., Enzyme rechnology, John Wiley and sons, Inc., New York (1943).

44. Green, L.E. and stompf, Y.K., Jo. biol. Lhem.,142, 355 (1942). 45. Cori, G.I. and Cori, C.F., Jo. Biol. hem., 135, 733 (1940). also Cori, G.I., Cori, C.F., and Green, L.E., Jo. Biol. Uhem. $151,21(1943)$.

46. Hidy, P.H., and Lay, H.G., op. cit.

47. Loudoroff, in. (1943) op. cit.

48. Colowick, s.P. and southerland, 上.W., Jo. Biol. Ehem., 144, 423 (1942).

49. Bergmann, M., and Fraenkel-conrat, H., op. cit. 